\title{
CHARACTERIZATION OF CHANGES IN COMPOSITION AND PHYSIOCHEMICAL PROPERTIES OF CASEIN MICELLES FROM RAW MILK TO BUTTERMILK
}

\author{
A Thesis \\ presented to \\ the Faculty of California Polytechnic State University, \\ San Luis Obispo
}

In Partial Fulfillment

of the Requirements for the Degree

Master of Science in Agriculture, with Specialization in Dairy Products Technology

by

Melissa A. Looney

March 2014 
(C)2014

Melissa A. Looney

ALL RIGHTS RESERVED 


\section{COMMITTEE MEMBERSHIP}

TITLE:

AUTHOR:

DATE SUBMITTED:

COMMITTEE CHAIR:

Professor of Dairy Science

COMMITTEE MEMBER: Yves Pouliot, $\mathrm{PhD}$

Professor of Food Science, Laval University, Canada

COMMITTEE MEMBER: Amy Lammert, PhD

Professor of Food Science

Characterization Of Changes In Composition And

Physiochemical Properties Of Casein Micelles From Raw Milk To Buttermilk

March 2014

Rafael Jimenez-Flores, PhD 


\begin{abstract}
Characterization Of Changes In Composition And Physiochemical Properties Of Casein Micelles From Raw Milk To Buttermilk

Melissa A. Looney
\end{abstract}

It is well-documented that buttermilk has poor coagulation properties due to changes that occur to the casein micelles during the butter-making process. These modifications are generally attributed to the pasteurization of the cream upon which interactions between the proteins are promoted. It was hypothesized that churning is also a critical step for the changes that occur in composition of the casein micelles. The objective of this work was to learn more about the interactions that occur between casein micelles and MFGM components during the butter making process.

Raw cream was processed using a rotary churn at $18^{\circ} \mathrm{C}$ for approximately 30 minutes, and buttermilk was collected for analysis. Raw milk was skimmed at $10^{\circ} \mathrm{C}$ by centrifuging at $3000 \mathrm{x}$ g for 20 minutes. Cream, skim milk and buttermilk were centrifuged at $60,000 \mathrm{x}$ g for 40 minutes twice using imidazole buffer at $\mathrm{pH} 6.8$ in order to isolate the micellar content in the pellet. Variation in physical properties of the casein micelles was determined using a Malvern Zetasizer. Protein profiles of UP cream, skim milk, and buttermilk were analyzed using one and two-dimensional gel electrophoresis technique. Experiments were performed using three different batches of UP cream, skim milk and buttermilk. Statistical analyses showed that processing the buttermilk significantly increased the surface charge $(\mathrm{P}<0.05)$ of the micelle but had no significant effect on their size $(\mathrm{P}>0.05)$. Our results also indicate that 
churning of cream promoted interactions between casein micelles and MFGM proteins as shown by the more complex 2D-gel electrophoresis pattern obtained for casein micelles sedimented from buttermilk. This work is significant in its focus of better understanding the functionality changes of valuable milk components during the churning of cream.

Keywords: Casein micelle, buttermilk, butter, MFGM proteins, phospholipids, minerals 


\section{ACKNOWLEDGMENTS}

I wish to thank my committee chair and advisor, Dr. Jimenez-Flores for his guidance and support during the last 6 years at Cal Poly. Thank you for giving me the opportunity to learn and grow at the DPTC.

I would like to thank Dr. Yves Pouliot for his graciousness during my one-year stay at Laval University. He allowed me to stay with Maxime while continuing my education and figuring out where I wanted to be in my career. During that one year in Québec City, I grew a lot as an individual, and I want to thank him for that opportunity.

I would also like to thank Dr. Amy Lammert for her support in the last 4 years that I have known her. Her laughter and conversation made me smile when I needed it the most!

I would like to thank those at University Laval as well as Cal Poly who helped me run my experiments. A big thank you to Diane Gagnon for helping me prepare my experiments in the lab at Laval and for being my personal translator whenever she could. Also, thank you for your conversations about cats and California. It helped me a lot when I was home-sick during the freezing cold winter! Thank you to Andrea Laubscher for helping me grow during the last 5 years in and outside of the lab. Your support means a lot to me, and I'm so glad to have worked with you! 
I would like to thank Dr. Leanne Berning for always having her door open to talk, for advising me in my academics, and giving me advice from my undergrad days until today.

Thank you to my family for supporting me throughout my last 7 years away from home. I couldn't have done it without you, thank you for believing in me and letting me tell you about my problems when I needed to.

Finally, a big thank you to Maxime Saffon. You changed my life and have supported me in every way possible throughout the last few years. I honestly couldn't have done this without your constant love and support. Thanks for always being my biggest fan. Also, thank you to your amazing family for believing in us and letting life take us wherever it may. I'm very proud of you for all that you have accomplished, and I can't wait to be with you during our next chapter. 


\section{TABLE OF CONTENTS}

LIST OF TABLES $\quad x$

LIST OF FIGURES xi

1. INTRODUCTION 1

2. LITERATURE REVIEW 4

2.1 Bovine Milk 4

2.1.1 Composition 4

2.1.2 Milk salt balance between soluble and colloidal phases of milk 6

$\begin{array}{ll}\text { 2.2. Casein Micelles } & 7\end{array}$

2.2.1 Composition and Characteristics 8

2.2.2 Proposed model for internal structure $\quad 12$

2.2.3 Isolation Methods of the Casein Micelle 14

2.2.3.1. Centrifugation 14

2.2.3.2. Ultrafiltration and microfiltration 15

$\begin{array}{lll}2.3 & \text { The Milk Fat Globule } & 15\end{array}$

2.3.1 Overall composition 16

2.3.2 The milk fat globule membrane: composition and structure 17

2.3.3 Method for isolating the milk fat globule membrane 22

2.4 Separation and processing of milk fat 23

2.4.1 Centrifugal separation (principle, equipment, and products generated) 24

2.4.2 Phase inversion and butter-making 26

2.4.3 Buttermilk composition, properties and utilization 28

2.5 Interactions between casein micelles and other milk components 31

2.5.1 Whey proteins 31

2.5.2 Other minor components 33

2.5.3 Fatty acids and other lipids 35

3. MATERIALS AND METHODS

$\begin{array}{lll}3.1 & \text { Materials } & 36\end{array}$

3.2 Preparation of raw cream, raw skim milk and raw buttermilk 36

$\begin{array}{lll}3.3 & \text { Isolation of casein micelles } & 37\end{array}$

$\begin{array}{lll}3.4 & \text { Analytical methods } & 38\end{array}$

3.4.1 Composition 38

3.4.2 Polyacrylamide gel electrophoresis $\quad 39$

3.4.2.1 One-dimensional PAGE 39

3.4.2.2 Two-dimensional PAGE 39

3.4.3 Particle size distribution and zeta potential of the casein micelles 41

3.4.4 Phosphorus content of micellar pellet $\quad 42$

3.4.4.1 Total Phosphorus 43

3.4.4.2 Total Phosphorus acid-soluble (esterified P, soluble+colloidal P) 44

3.4.4.3 Acid-soluble Inorganic Phosphorus (soluble+colloidal) 44

3.4.5 Freeze-drying of micellar pellet 45

3.4.6 Cation content of micellar pellet 45 
3.4.6.1 Total Calcium (Ca), Potassium (K), Sodium (Na), and Magnesium (Mg) 46

3.4.6.2 Soluble $\mathrm{Ca}, \mathrm{K}, \mathrm{Na}, \mathrm{Mg}$ :

3.5 Statistical analysis

4. RESULTS

4.1 Compositional analysis and mass balance of milk components

4.2 One-Dimensional Gel Electrophoresis

4.3 Particle size distribution and $\zeta$-potential

4.4 Two-Dimensional Gel Electrophoresis

4.5 Salt content of micellar pellets

4.6 Phosphorus

5. GENERAL DISCUSSION

6. GENERAL CONCLUSIONS

7. REFERENCES 


\section{LIST OF TABLES}

Table 2.1. Gross composition of bovine whole milk (Walstra et al., 1999)

Table 2.2. Minerals and salts composition and distribution in milk adapted from Walstra et al. (2006) .......6

Table 2.3. Approximate composition of bovine casein micelles from (McMahon and Brown, 1984)............8

Table 2.4. Average characteristics of casein micelles from (Fox and McSweeney, 2003).........................11

Table 2.5. Variation of electrokinetic potential of casein micelles with temperature and pH (McMahon and Brown, 1984)

Table 2.6. Estimated composition of the milk fat globule membrane adapted from (Goff and Hill, 1993;

Walstra et al., 2006).

Table 2.7.Main physical and chemical properties of proteins of the milk fat globule membrane adapted from Cheng et al. (1988), Dewettinck et al. (2008), Heid et al. (1996), Hvarregaard et al. (1996), Pallesen et al. (2001), Singh (2006), and Stammers et al. (2000).

Table 2.8. Lipid composition of the milk fat globule membrane from Keenan and Dylewski (1995) and Walstra et al. (2006).

Table 2.9. Examples of the proposed conditions for the washing of the cream for isolation of MFGM from whole milk (row 1) and buttermilk (row 2-3) (Dewettinck et al., 2008)

Table 2.10. Comparison between the gross composition of buttermilk and skim milk (Ramachandra Rao et al., 1995; Walstra et al., 2006).

Table 4.1: Proteins identified in the micellar pellet isolated from raw cream. Identification was realized according to Fong et al. (2007) (ID $)$, Bédard $S^{T}$-Amand (2009) (ID 2$)$ or molecular weight $(\mathrm{MW}) /$ isoelectric point $(\mathrm{pI})$.

Table 4.2: Proteins identified in the micellar pellet isolated from raw skim milk. Identification was realized according to Fong et al. (2007) (ID $)$, Bédard $S^{T}$-Amand (2009) (ID $)$ or molecular weight $(M W) /$ isoelectric point $(p I)$.

Table 4.3: Proteins identified in the micellar pellet isolated from raw buttermilk. Identification was realized according to Fong et al. (2007) (ID $)$, Bédard $S^{T}$-Amand (2009) (ID $)$ or molecular weight $(M W) /$ isoelectric point $(p I)$.

Table 4.4: Proteins identified in the milk-fat globule membrane sample isolated from raw buttermilk. Identification was realized according to Fong et al. (2007) (ID $)$, Bédard $S^{T}$-Amand (2009) $\left(\mathrm{ID}_{2}\right)$ or molecular weight $(\mathrm{MW}) /$ isoelectric point $(\mathrm{pI})$.

Table 4.5: Total mineral content (means \pm SD) found in raw cream, skim milk, and buttermilk; $n=4 \ldots \ldots . .60$

Table 4.6: Soluble mineral content (means \pm SD) found in raw cream, skim milk, and buttermilk; $n=4$....60

Table 4.7: Phosphorus contents (means \pm SD) of raw cream, skim milk, and buttermilk; $n=4$. .62 


\section{LIST OF FIGURES}

Figure 2.1. Salts equilibrium in milk from (Britten and Pouliot, 2002) ....................................................7

Figure 2.2. Schematic representation of the casein micelle adapted from Horne (2006)..........................13

Figure 2.3. Structure of the milk fat globule from (Dewettinck et al., 2008) ...........................................16

Figure 2.4. Schematic representation of the bovine milk fat globule membrane from Brisson et al. (2010), Gallier et al.(2010), and Gallier et al.(2011).

Figure 2.5. Cutaway diagram of a centrifugal separator (a) and the bowl (b). The paths of milk and cream fractions can be observed (O'Mahony, 1988). ........................................................25

Figure 2.6. Example of an industrial milk fat separator ...................................................................26

Figure 2.7. The different stages of the formation of butter adapted from Mulder and Walstra (1974). The fat is represented in white and the serum in black.

Figure 2.8. Example of a continuous butter churn from (Bylung, 1995). 1 corresponds to a variablespeed motor; 2 to separation section; 3 to a squeeze-drying section; 4 to a second working section; 5 to a high-pressure injector (for salt)

Figure 2.9: Schematic representation of the association of the casein micelle with whey proteins (Bylung, 1995).

Figure 3.1: Experimental procedure used to prepare the raw cream, raw skim milk, and raw buttermilk ...37

Figure 3.2: Experimental procedure used to isolate the casein micelles from the raw cream, raw skim

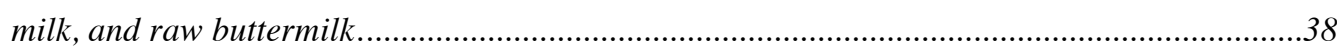

Figure 3.3: Experimental procedure used to determine phosphorus content of casein pellets. . .43

Figure 4.1: Summary of the evolution of the protein content (in \%) and protein mass (in g) during the isolation of the casein micelle of buttermilk.....

Figure 4.2:One-dimensional gel of casein micelles from the ultracentifugation of raw cream, skim milk, and buttermilk. Key: 1) Broad range molecular weight ladder, 2) buttermilk supernatant 1(diluted 4:1), 3) buttermilk supernatant 2 (diluted 4:1), 4) buttermilk pellet (4.9mg/mL), 5) skim supernatant 1 (diluted 4:1), 6) skim supernatant 2 (diluted 4:1), 7) skim pellet $(4.9 \mathrm{mg} / \mathrm{mL}), 8)$ cream supernatant 1 (diluted 4:1), 9) cream supernatant 2 (diluted 4:1), 10) cream pellet $(4.9 \mathrm{mg} / \mathrm{mL})$

Figure 4.3: Identification of the proteins from the micellar pellet of buttermilk $(4.9 \mathrm{mg} / \mathrm{mL})$ in accordance to their molecular weight.

Figure 4.4: Average particle size distribution from raw cream, skim milk, and buttermilk micellar pellets. Means with a different letter are statistically different from each other.

Figure 4.5: Average zeta potential of particles from raw cream, skim milk, and buttermilk micellar pellets. Means with a different letter are statistically different from each other. 
Figure 4.6: 2D-PAGE gel separation of proteins from micellar pellets isolated from raw cream. The gel was loaded with approximately $250 \mu \mathrm{g}$ of proteins and was stained with GelCode Blue Stain. The numbers associated with some spots refer to protein numbers in Table 4.1.

Figure 4.7: 2D-PAGE gel separation of proteins from micellar pellets isolated from raw skim milk. The gel was loaded with approximately $250 \mu \mathrm{g}$ of proteins and was stained with GelCode Blue Stain. The numbers associated with some spots refer to protein numbers in Table 4.2 ....55

Figure 4.8: 2D-PAGE gel separation of proteins from micellar pellets isolated from raw buttermilk. The gel was loaded with approximately $250 \mu \mathrm{g}$ of proteins and was stained with GelCode Blue Stain. The numbers associated with some spots refer to protein numbers in Table 4.3....56

Figure 4.9: 2D-PAGE gel separation of proteins from milk-fat-globule membrane isolated from raw buttermilk. The gel was loaded with approximately $250 \mu \mathrm{g}$ of proteins and was stained with GelCode Blue Stain. The numbers associated with some spots refer to protein numbers in Table 4.4 . .59 


\section{INTRODUCTION}

In 2012, the butter production in the United States totaled 0.84 billion kilograms, which is 2.8 percent above the production of 2011. California accounted for 35.2 percent of the production. Due to the increase of butter production, the production of buttermilk is also increasing. For example, the annual production of buttermilk powder in the US in 2011 was estimated to be 45 million kilograms (USDA, 2013).

Buttermilk is the aqueous phase obtained after the process of churning cream. It has a composition similar to that of skim milk, and is predominantly made up of the watersoluble compounds of cream such as protein, lactose and minerals (Ramachandra Rao et al., 1995; Walstra et al., 2006). However, buttermilk is a unique product in that there are residual fragments of the milk fat globule membrane (MFGM) as well as associated material (proteins, phospholipids, and sphingolipids) that have been linked to positive health benefits and nutritional aspects. Unfortunately, buttermilk has not found many industrial applications yet due to the following limitations:

1) Buttermilk is a complex byproduct for the dairy industry because it contains low total solids and is very sensitive to degradation and oxidation; it has to be processed into a powder quickly in order to extend its shelf life. This often makes it unusable for food applications, and therefore buttermilk powder is rather used in animal nutrition (Morin, 2006).

2) Processing of cream, especially pasteurization, modifies the properties of the soluble components found in buttermilk, such as loss of the coagulation properties of the protein, as well as loss of the components associated with the MFGM 
(Morin, 2006).

3) The high water holding capacity of the phospholipids found in buttermilk limits it's use in cheese making (Turcot et al., 2002; Turcot et al., 2001). For example, (Mistry et al., 1996) found that it is possible to substitute milk with liquid buttermilk without causing any textural defects if the amount of buttermilk does not exceed $5 \%$ of the total volume. Also, it has been shown that high levels of phospholipids in buttermilk creates a limitation in its use in cheese making because of poor curd fusion and high humidity of cheeses (Turcot et al., 2001).

4) Isolation of its components has been shown to be difficult due to the similarity between the size of the casein micelles and the MFGM fragments (Morin, 2006).

However, various components of buttermilk, such as caseins, could be used in many foods applications. Caseins represent roughly $75 \%$ of the total proteins found in buttermilk (Sodini et al., 2006). For example, caseins are responsible for the rennetinduced coagulation of cheese or acid-type gels (yogurts). Unfortunately, the butter churning process, and particularly the pasteurization of cream, has been shown to affect the technological properties of these casein micelles. Moreover, from the recent work of Zheng et al. (2013), it has been hypothesized that the mechanical treatments involved in the skimming of milk may affect the integrity of the external layer of milk fat globule, and therefore release surface-active compounds in skim milk. These contaminant molecules could in turn interact with casein micelles and explain the poor technological properties. To our knowledge, there are no studies that report on the effect of the physical treatment (skimming or churning) on 
physicochemical properties of the casein micelle.

The goal of the current project was to characterize some changes that occur to the casein micelles during the physical treatment (skimming and churning) involved during the butter making process. In particular, the effect of skimming and churning on the composition (protein, mineral) of the casein micelle from raw buttermilk (unpasteurized) were investigated.

Previous studies have clearly demonstrated that pasteurization of cream affects the functional properties of the casein micelles (Morin, 2006). The general hypothesis of this work was that a better understanding of the effect of skimming and churning on the properties of the casein micelle could offer new opportunities for the utilization of buttermilk.

The objectives for this work were:

1) To develop a standardized approach for the isolation of casein micelles from raw milk, cream and buttermilk.

2) To characterize the effect of skimming and churning on the composition (protein, salts) of casein micelles from raw milk.

3) Relate the compositional changes (protein \& salts) to changes in micellar size and charge (zeta potential). 


\section{LITERATURE REVIEW}

\subsection{Bovine Milk}

Milk is a white liquid secreted by all female mammals in order to fulfill the nutrition need and immunological protection of their young. Bovine milk is by far the most produced milk around the world $(\sim 83 \%$ of total milk) with a worldwide production of 606 million tons in 2011. The United States of America is the largest bovine milk producer with around 89 million tons produced in 2011 (FAO, 2013).

\subsubsection{Composition}

Bovine whole milk is mostly composed of water $(87 \mathrm{~g} / 100 \mathrm{~g})$. The solids are divided into carbohydrates $(4.6 \mathrm{~g} / 100 \mathrm{~g})$, fat $(4.0 \mathrm{~g} / 100 \mathrm{~g})$, proteins $(3.3 \mathrm{~g} / 100 \mathrm{~g})$, salts $(0.72 \mathrm{~g} / 100 \mathrm{~g})$, and miscellaneous components as summarized in Table 2.1 (Walstra et al., 1999). However, there are some variations in the composition of bovine whole milk depending on the breed of the cow, stage of lactation, the season, and feed. 
Table 2.1. Gross composition of bovine whole milk (Walstra et al., 1999)

\begin{tabular}{|c|c|}
\hline Constituents & $\begin{array}{l}\text { Bovine Whole Milk } \\
(\mathrm{g} / 100 \mathrm{~g})\end{array}$ \\
\hline Water & 87 \\
\hline Carbohydrates & 4.6 \\
\hline Lactose & 4.59 \\
\hline Fat & 4.0 \\
\hline Proteins & 3.3 \\
\hline Caseins & 2.64 \\
\hline Whey proteins & 0.66 \\
\hline Salts & 0.72 \\
\hline
\end{tabular}

Minerals in milk, as well as in buttermilk, are distributed between the serum phase and within the casein micelles, called the colloidal phase. The casein micelles contain the undissolved salts. The undissolved salt is briefly called the colloidal, or micellar, calcium phosphate, though it includes other components such as $\mathrm{K}, \mathrm{Na}, \mathrm{Mg}$, and citrate. The salts present in the serum phase affect various milk properties such as protein stability. Table 2.2 shows the average content of the major minerals and its distribution between serum and colloidal phase. 
Table 2.2. Minerals and salts composition and distribution in milk adapted from Walstra et al. (2006)

\begin{tabular}{|c|c|c|c|}
\hline Components & mg/100 g of Milk & $\%$ Soluble phase & $\%$ Colloidal phase \\
\hline $\mathrm{Na}$ & 48 & 95 & 5 \\
\hline K & 143 & 94 & 6 \\
\hline $\mathrm{Ca}$ & 117 & 32 & 68 \\
\hline $\mathrm{Mg}$ & 11 & 66 & 34 \\
\hline $\mathrm{Cl}$ & 110 & 100 & 0 \\
\hline $\mathrm{CO} 3$ & 10 & $\sim 100$ & 0 \\
\hline SO4 & 10 & 100 & 0 \\
\hline PO4 & 203 & 53 & 47 \\
\hline Citrate & 175 & 92 & 8 \\
\hline
\end{tabular}

\subsubsection{Milk salt balance between soluble and colloidal phases of milk}

Salt equilibrium in milk and buttermilk are comparable. Changing external conditions of milk may cause alterations in equilibria. For example, calcium phosphate is sensitive to several processing parameters. Modification of the $\mathrm{pH}$ and temperature treatments can affect the equilibrium of calcium phosphate. Figure 2.1 shows the equilibrium of milk salts. 


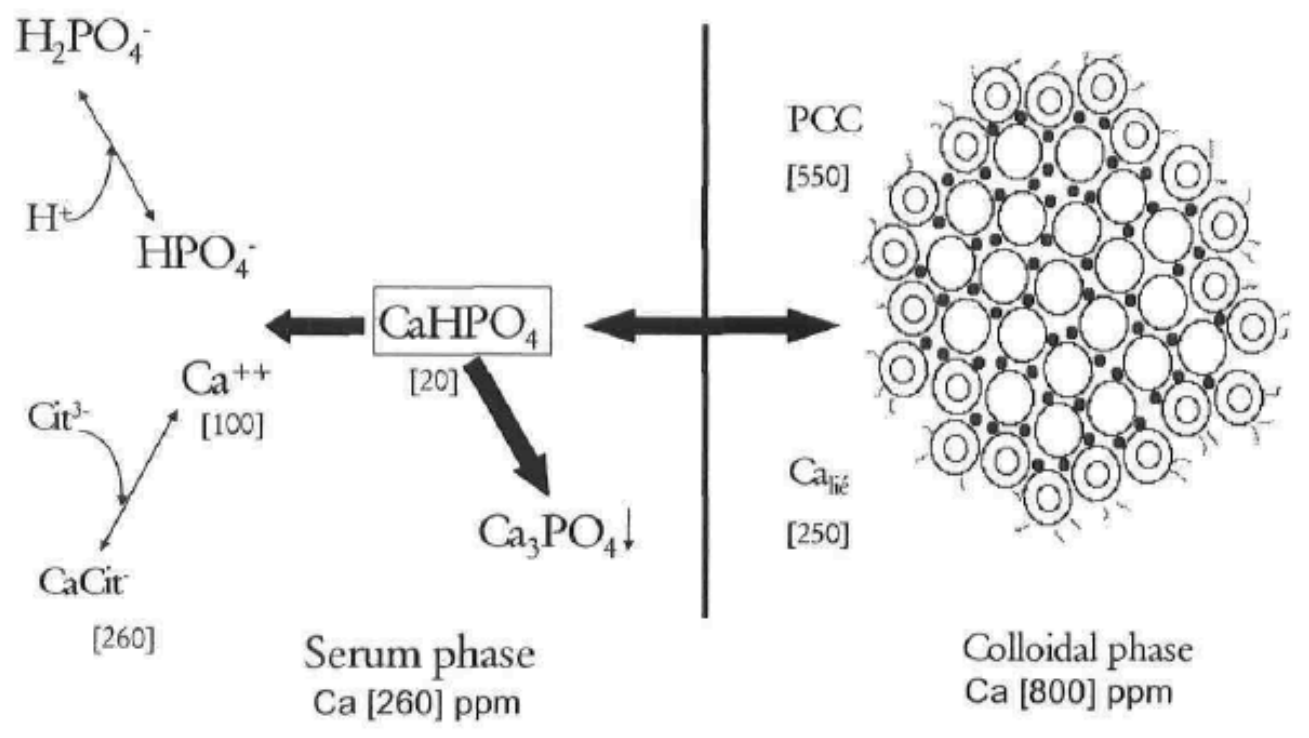

Figure 2.1. Salts equilibrium in milk from (Britten and Pouliot, 2002).

Lowering the $\mathrm{pH}$ of milk decreases its stability of the casein micelle through demineralization. Likewise, cooling the temperature of milk is associated with demineralization of casein micelle that is reversible, caused by an increase in calcium phosphate solubility, dragging the equilibrium towards the serum phase (Pierre and Brule, 1981). Alternatively, heating milk decreases the solubility of calcium phosphate (Gaucheron et al., 2004). If heat treatment is over $80^{\circ} \mathrm{C}$, then there is formation of insoluble calcium phosphate.

\subsection{Casein Micelles}

Caseins are the predominant proteins in buttermilk with around $75 \%$ of the total protein content (Walstra et al., 2006). Caseins are unique because they have little secondary and 
tertiary structures. The characteristics of the casein are important in determining the rheological properties of fermented dairy products.

\subsubsection{Composition and Characteristics}

In a milk system, caseins are present as colloidal particles named casein micelles. The casein micelles contain inorganic matter as calcium phosphate, which makes up about $8 \mathrm{~g} / 100 \mathrm{~g}$ casein. Likewise, the casein micelle structure also contains a small percentage of other proteins, such as the proteose peptone or other enzymes as shown in Table 2.3.

Table 2.3. Approximate composition of bovine casein micelles from (McMahon and Brown, 1984).

\begin{tabular}{llll}
\hline Components & Content & Components & Content \\
& $(\mathrm{g} / 100 \mathrm{~g}$ of micelles $)$ & & $(\mathrm{g} / 100 \mathrm{~g}$ of micelles $)$ \\
\hline$\alpha \mathrm{S} 1$-casein & 35.6 & Magnesium & 0.1 \\
$\alpha \mathrm{S} 2$-casein & 9.9 & Sodium & 0.1 \\
$\beta$-casein & 33.6 & Potassium & 0.3 \\
$x$-casein & 11.9 & Citrate & 0.4 \\
Minor casein & 2.3 & Sialic acid & 0.3 \\
Calcium & 2.9 & Galactose & 0.2 \\
Phosphate & 2.9 & Galactosamide & 0.2 \\
\hline
\end{tabular}

As shown in Table 2.3, caseins micelles are composed of four major proteins: $\alpha_{\mathrm{S} 1}(33 \%)$, $\beta(33 \%), \alpha_{\mathrm{S} 2}(11 \%)$, and $\varkappa(11 \%)$ (Brulé et al., 1997; Walstra et al., 2006). The presence of casein micelles in milk is very important because it determines the physical stability of 
milk products during process and storage and the viscosity of products concentrated in proteins (Walstra et al., 2006). Each protein has unique characteristics, and contributes to the overall integrity of the micelle.

The protein $\alpha_{\mathrm{S} 1}$-casein is the predominant form of casein found, with a molar mass of 23,614 Da and 199 amino acid residues per molecule (Walstra et al., 2006). It has the highest charge and the highest phosphate content and contains no cysteine molecules.

The protein $\alpha_{\mathrm{s} 2}$-casein is the most hydrophilic and most calcium sensitive of all the caseins; they precipitate at a $\mathrm{Ca}^{2+}$ concentration of less than $2 \mathrm{mM}$ (Walstra et al., 2006). It contains two cysteine residues and no carbohydrate groups. Under non-reducing conditions, as2-caseins exist as a disulphide-linked dimer.

The most hydrophobic fraction of the caseins are $\beta$-caseins, which are less sensitive to calcium salt, precipitating at a range of $8-15 \mathrm{mM} \mathrm{Ca}^{2+}$ at $37{ }^{\circ} \mathrm{C}$ (Swaisgood, 2003). It has a large number of proline residues. The charge of $\beta$-casein is unevenly distributed, making it comparable to a soap-like structure with a hydrophilic charged "head" toward the center of the micelle and hydrophobic end. Below $5^{\circ} \mathrm{C}$ no association of $\beta$-casein occurs and the molecule remains unfolded.

The protein fraction $x$-casein differs greatly from the other caseins due to the presence of two cysteine residues that form an intermolecular disulfide bond $\left(\mathrm{Cys}_{11}-\mathrm{Cys}_{88}\right)$. $x$-caseins play an extremely important physiological role in maintaining the integrity of the micelle 
structure by stabilizing the caseins in the presence of calcium ions in milk. Under a hypothesized model proposed by Holt and Horne (1996), $x$-casein forms a "hairy layer" on the surface of micelles and is responsible for stabilizing the micelles sterically and electrostatically from aggregation.

Casein micelles are generally spherical in shape with an average diameter of $\sim 150 \mathrm{~nm}$, ranging from 50 to $500 \mathrm{~nm}$, and an average mass of $\sim 10^{8} \mathrm{Da}$ (Table 2.4). However, each micelle is different, and some variation can be observed. In particular, the proportion of $x$-casein varies, which plays a large part in the overall variation in size of the casein micelle. 
Table 2.4. Average characteristics of casein micelles from (Fox and McSweeney, 2003).

\begin{tabular}{|c|c|c|c|}
\hline Characteristic & Value & Characteristic & Value \\
\hline Diameter & $130-160 \mathrm{~nm}$ & Voluminosity & $4.4 \mathrm{~cm}^{3} / \mathrm{g}$ \\
\hline Surface & $8 \times 10^{-10} \mathrm{~cm}^{2}$ & $\begin{array}{l}\text { Molecular weight } \\
\text { (hydrated) }\end{array}$ & $1.3 \times 10^{9} \mathrm{Da}$ \\
\hline Volume & $2.1 \times 10^{-15} \mathrm{~cm}^{3}$ & $\begin{array}{l}\text { Molecular weight } \\
\text { (dehydrated) }\end{array}$ & $5 \times 10^{4} \mathrm{Da}$ \\
\hline Density (hydrated) & $1.0632 \mathrm{~g} / \mathrm{cm}^{3}$ & $\begin{array}{l}\text { Number of peptide } \\
\text { chains (MW: } 30,000 \\
\text { Da) }\end{array}$ & $10^{4}$ \\
\hline Mass & $2.2 \times 10^{-15} \mathrm{~g}$ & $\begin{array}{l}\text { Number of particles } \\
\text { per ml milk }\end{array}$ & $10^{14}-10^{16}$ \\
\hline Water content & $63 \%$ & $\begin{array}{l}\text { Whole surface of } \\
\text { particle }\end{array}$ & $5.10^{4} \mathrm{~cm}^{2} / \mathrm{mL}$ milk \\
\hline Hydration & 3.7 $\mathrm{g} \mathrm{H}_{2} \mathrm{O} / \mathrm{g}$ protein & Mean free distance & $240 \mathrm{~nm}$ \\
\hline
\end{tabular}

Zeta potential has been directly related to the colloidal stability of the casein micelle. The calculated electrokinetic potential, $(\zeta$-potential) of casein micelles vary with both $\mathrm{pH}$ and temperature. As seen in Table 2.5, the $\zeta$-potential decreases with both $\mathrm{pH}$ and temperature measured. However, heat treatment itself has no significant effect. Milk can be heated prior to coagulation without exhibiting any consistent change of $\zeta$-potential (Darling and Dickson, 1979). Calculations of casein micelle zeta potentials vary because 
the micelle surface is irregular, and its double layer has an unknown structure. The $\zeta-$ potentials of casein micelles immersed in a medium of the same ionic strength as milk depend only upon the surface charge density of the micelles. Size of the micelle does not contribute to electrokinetic potential. Fixed charges within the micelle are partially neutralized by serum ions and do not contribute to electrokinetic potential.

Table 2.5. Variation of electrokinetic potential of casein micelles with temperature and pH (McMahon and Brown, 1984).

\begin{tabular}{llll}
\hline & & \multicolumn{2}{c}{ Potential $(\mathrm{mV})$} \\
$\mathrm{pH}$ & $20^{\circ} \mathrm{C}$ & $30^{\circ} \mathrm{C}$ & $45^{\circ} \mathrm{C}$ \\
\hline 5.7 & -8 & -10 & -14 \\
6.8 & -13 & -17 & -22 \\
\hline
\end{tabular}

\subsubsection{Proposed model for internal structure}

Over the years, various structural models have been proposed for the casein micelles. The first attempt to describe the structure of the casein micelle was made by Waugh in 1958 and, since then, numerous models have been made and refined. The features that are found in any micelle model proposed throughout the years are the following: $x$-casein, which represents $\sim 15 \%$ of total casein, must be able to stabilize the calcium-sensitive $\alpha$ s1 -, $\alpha$-s2 - and $\beta$-caseins which represent approximately $85 \%$ of total casein; chymosin and other rennets hydrolyze most of the $x$-casein very rapidly; when heated in the presence of whey proteins, $x$-casein and $\beta-\mathrm{Lg}(\mathrm{MW} \sim 36 \mathrm{kDa}$ ) interact to form a disulfide-linked complex, which modifies the rennet and heat coagulation properties of the micelles. 
Modification of the micelle reveals some of its unique characteristics. For example, removal of colloidal calcium phosphate $(\mathrm{CCP})$ causes disintegration of the micelles into particles of $\mathrm{MW} \sim 10^{6} \mathrm{Da}$, which suggests that the casein molecules are held together in the micelles by CCP. Alternatively, at low temperatures, casein, particularly $\beta$-casein, dissociates from the micelles.

The most continuingly referred to model has been introduced by Schmidt (1980), and consists of submicelles connected together via hydrophobic bonds and calcium phosphate (Figure 2.2). In this submicelle model, the caseins first aggregate via hydrophobic interactions into subunits of 20 to 25 molecules and have an average diameter that ranges from 12 to 15 nanometers. Each submicelle contains different casein molecules, but it is important to remember that not all submicelles have the same composition.
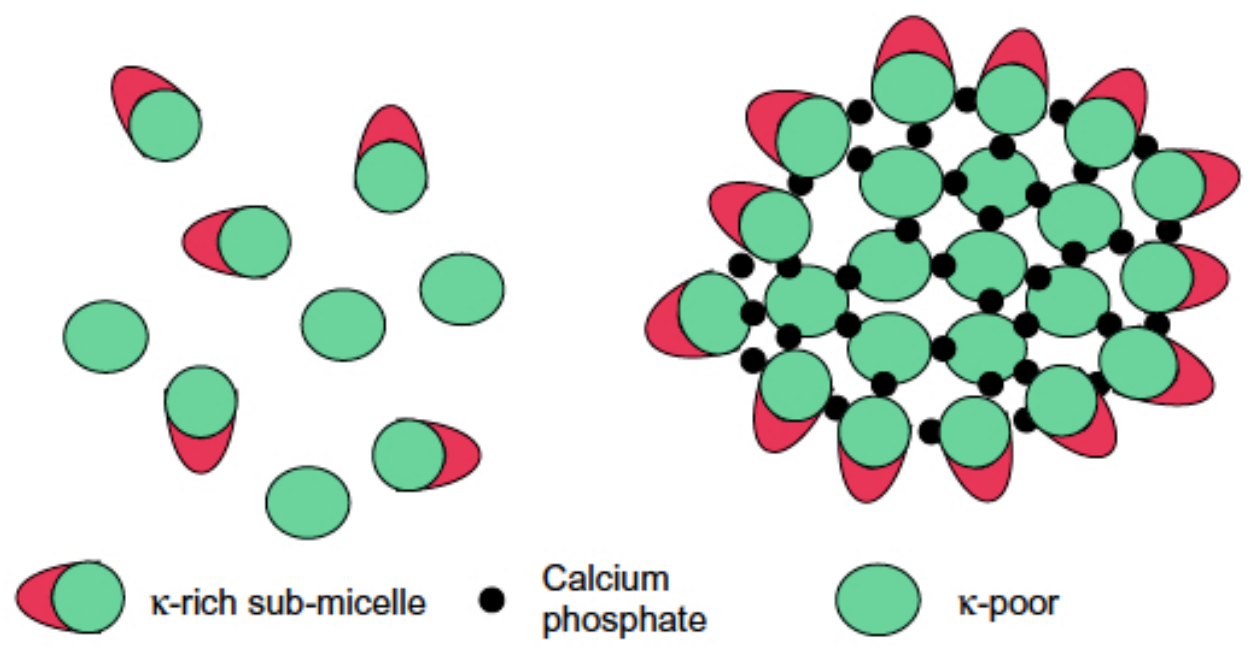

Figure 2.2. Schematic representation of the casein micelle adapted from Horne (2006). 


\subsubsection{Isolation Methods of the Casein Micelle}

There are many methods that can be used for the isolation of the casein micelle from bovine milk (Fox and McSweeney, 2003).

The protein fractions may be prepared from whole or skimmed milk, but the latter is usually used because the fat is covered in isoelectric casein and interferes with further characterization of the proteins. The fat is easily removed from milk by centrifugation (3000 x g for $30 \mathrm{~min}$ ). Following the removal of fat from whole milk, there are a few methods used for separating protein fractions. Isoelectric precipitation at $\mathrm{pH} 4.6$ at $20^{\circ} \mathrm{C}$ is the most widely used method for separating the casein and non-casein fractions of milk protein but several other techniques are used in certain situations (Fox and McSweeney, 2003). Highlighted below are a few methods used to separate the casein and non-casein fractions of milk protein.

\subsubsection{Centrifugation}

In milk, the casein exists as large micelles that may be sedimented by centrifugation at $100,000 \mathrm{x}$ g for 1 hour; the whey proteins are soluble and do not sediment. The pellet obtained contains its original level of colloidal calcium phosphate, and can be dispersed in a suitable buffer as micelles with properties essentially similar to the original micelles. This method is ideal for maintaining the native form of the micelle and is often used in the laboratory setting (Thompson et al., 2009). 


\subsubsection{Ultrafiltration and microfiltration}

All the milk proteins can be retained by small pore, semi-permeable membranes and are separated from lactose and soluble salts. Ultrafiltration is used for the industrial-scale production of whey protein concentrates (WPCs) and to a lesser extent for the production of total milk protein. Intermediate-pore membranes are used to separate casein micelles from whey proteins. In microfiltration, using large-pore membranes $(0.4 \mu \mathrm{m})$, both the caseins and the whey proteins are permeable, but $99.9 \%$ of bacteria and other large particles are retained (Thompson et al., 2009).

\subsection{The Milk Fat Globule}

The fat globules ( 3 to $5 \%$ of total fat in bovine whole milk) consist of a triglyceride core surrounded by a thin membrane called the milk fat globule membrane (MFGM). The membrane of the fat globule (approximately 10 to $20 \mathrm{~nm}$ in diameter) acts as an emulsifier and protects the globules from coalescence and enzymatic degradation (Dewettinck et al., 2008). The distribution of the globules corresponds to tiny and spherical droplets or globules stabilized in the form of an emulsion (Singh, 2006). The diameter of a milk fat globule varies from $0.1 \mu \mathrm{m}$ to $20 \mu \mathrm{m}$ with an average around 3 to $5 \mu \mathrm{m}$ (Danthine et al., 2000). It should be noted that the distribution and size of globules depends on the breed of cow, stage of lactation, and feed. For example, the average size of milk fat globule from Jersey cows' milk is approximately $4.5 \mu \mathrm{m}$ while it is $3.5 \mu \mathrm{m}$ for Friesian cows' milk (Singh, 2006). The microstructure and the size of the fat globule are essential for the texture of dairy products such as cheese. The smaller globules are more resistant to disruption during processing, have a higher ratio of MFGM to triacylglycerides, and will 
yield higher retention of the membrane in cheese curds. However, the moisture of the curd will increase due to the high water-holding capacity of the MFGM (Goudedranche et al., 2000; Lopez, 2007).

\subsubsection{Overall composition}

As shown in Figure 2.3, a milk fat globule is composed of a lipid core surrounded by an inner monolayer membrane and an outer double layer membrane.

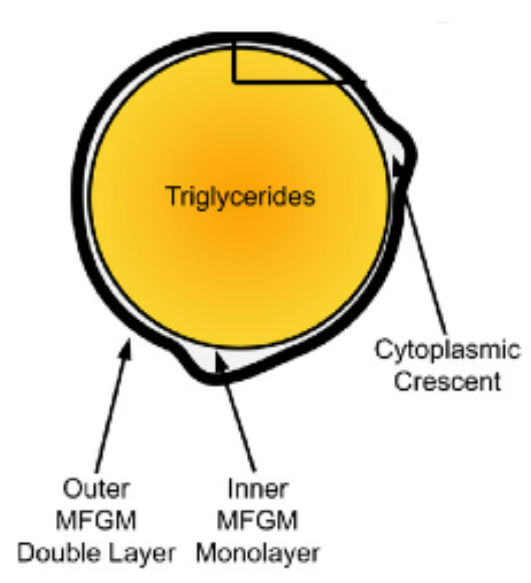

Figure 2.3. Structure of the milk fat globule from (Dewettinck et al., 2008).

The lipid cores is mostly composed of triglycerides, but also di- and monoglycerides, fatty acids, cholesterols, carotenoids and fat-soluble vitamins. The average composition depends on the size of the globule, and the overall characteristics and can be affected by processing or environmental conditions (Lopez et al., 2008; Mulder and Walstra, 1974). 


\subsubsection{The milk fat globule membrane: composition and structure}

The bovine milk fat globule membrane (MFGM) represents between $2 \%$ and $6 \%$ of the total mass of the fat globule and is composed of a complex mix of proteins, glycoproteins, phospholipids, triglycerides, cholesterol, enzymes and minor constituents (Keenan and Mather, 2006; Walstra et al., 2006). The gross composition of the MFGM is given Table 2.6.

Table 2.6. Estimated composition of the milk fat globule membrane adapted from (Goff and Hill, 1993; Walstra et al., 2006).

\begin{tabular}{lll}
\hline Components & $\mathbf{m g} / \mathbf{1 0 0} \mathbf{g}$ of fat globules & g/100 g of MFGM (dry matter) \\
\hline Protein & 1800 & 70 \\
Phospholipids & 650 & 25 \\
Cerebrosides & 80 & 3 \\
Cholesterol & 40 & 2 \\
Monoglycerides & Present & Presence unknown \\
Water & Present & $/$ \\
Carotenoids + Vit. A & 0.04 & 0.0 \\
Fe & 0.3 & 0.0 \\
Cu & 0.01 & 0.0 \\
Total & $>\mathbf{2 5 7 0}$ & $\mathbf{1 0 0}$ \\
\hline
\end{tabular}

The protein content of the MFGM varies from 25 to $60 \%$ depending on the method of extraction. It has been reported that the membrane contains over 40 proteins. Their nomenclature has been clarified by Mather (2000) as follow (major protein only): Mucin 
1 (MUC1), Xanthine Dehydrogenase/Oxidase (XDH/XO), Perodic Acid Schiff III (PAS III), Cluster of Differentiation (CD36), Butyrophilin (BTN), Adipophilin (ADPH), Periodic Acid Schiff 6/7 (PAS 6/7), and Fatty-Acid Binding Protein (FABP). The main characteristics of these proteins are summarized in Table 2.7. 
Table 2.7.Main physical and chemical properties of proteins of the milk fat globule membrane adapted from Cheng et al. (1988), Dewettinck et al. (2008), Heid et al. (1996), Hvarregaard et al. (1996), Pallesen et al. (2001), Singh (2006), and Stammers et al. (2000).

\begin{tabular}{|c|c|c|c|c|c|c|}
\hline Proteins & $\begin{array}{l}\% \text { of } \\
\text { total protein }\end{array}$ & $\begin{array}{l}\text { Molecular } \\
\text { Weight (kDa) }\end{array}$ & pI & -SS- (SH) & $\begin{array}{l}\mathbf{T}_{\mathrm{d}} \\
\left({ }^{\circ} \mathbf{C}\right)\end{array}$ & Role \\
\hline MUC1 & $n . f$. & 160 to 200 & $<4.5$ & $0(0)$ & $n . f$. & $\begin{array}{l}\text { Protective } \\
\text { effect against } \\
\text { physical } \\
\text { damage and } \\
\text { rotavirus }\end{array}$ \\
\hline XDH/XO & 20 & 150 & 7.7 & $11(38)$ & $<60$ & $\begin{array}{l}\text { Antimicrobial } \\
\text { function (gut) }\end{array}$ \\
\hline PAS III & 5 & 95 to 100 & $n . f$. & $n . f$. & $n . f$. & unknown \\
\hline CD36 & 5 & 76 to 78 & $n . f$. & $3(0)$ & $n . f$. & $\begin{array}{l}\text { Scavenger } \\
\text { receptor }\end{array}$ \\
\hline BTN & 20 to 43 & 67 & 5.0 to 5.4 & $1(0)$ & 58 & unknown \\
\hline ADPH & $n . f$. & 52 & 7.5 to 7.8 & $n . f$. & $n . f$. & $\begin{array}{l}\text { Possible } \\
\text { mediator for } \\
\text { lipid-protein } \\
\text { interactions }\end{array}$ \\
\hline PAS 6/7 & $n . f$. & 47 to 52 & 5.6 to 7.6 & $9(0)$ & $>80$ & unknown \\
\hline FABP & $n . f$. & 13 & $n . f$. & $n . f$. & $n . f$. & unknown \\
\hline
\end{tabular}


The overall $\mathrm{pI}$ of the MFGM has been determined to be around 4.8, meaning that at a higher $\mathrm{pH}$, the membrane will be charged negatively (Kanno and Kim, 1990).

As shown in Figure 2.4, the proteins are located throughout the membrane at different positions. Most of the main proteins are trans-membrane protein of the outer layer, also called serum-exposed side, such as MUC1, PAS III, BTN, and PAS 6/7. On the other hand, $\mathrm{XDH} / \mathrm{XO}$ is a peripheral-attached protein, $\mathrm{CD} 36$ is in the intracellular side of the membrane and ADPH is in the inner polar lipid monolayer (Dewettinck et al., 2008; Mather, 2000). MUC1, CD36, BTN, ADPH, are strongly attached to the membrane meaning that they cannot be removed from the membrane even in the presence of detergent or gravity (centrifugation). Oppositely, XDH/XO, PAS 6/7, and FABP are weakly attached to the membrane.

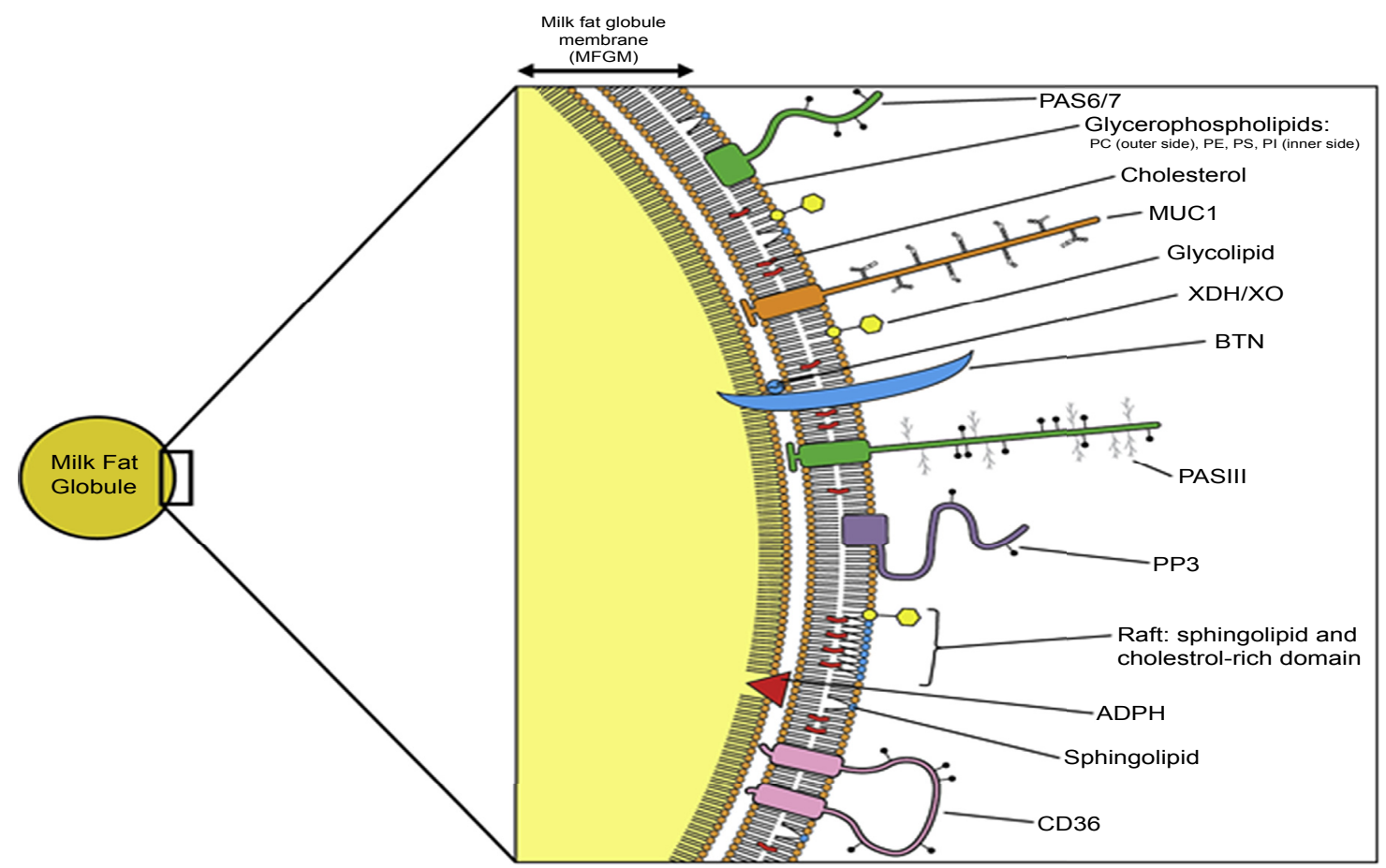

Figure 2.4. Schematic representation of the bovine milk fat globule membrane from Brisson et al. (2010), Gallier et al. (2010), and Gallier et al. (2011). 
In bovine milk, about 50 to $60 \%$ of the phospholipids are attached to the MFGM (fragmented or not), and they represent 26 to $31 \%$ of the total lipid concentration of the membrane (McPherson and Kitchen, 1983; Singh, 2006). The lipid composition of the MFGM is presented Table 2.8.

Table 2.8. Lipid composition of the milk fat globule membrane from Keenan and Dylewski (1995) and Walstra et al. (2006).

\begin{tabular}{ll}
\hline Constituents & \% of total lipids \\
\hline Triglycerides & 62 \\
Diglycerides & 9 \\
Sterols & 0.2 to 2.0 \\
Free fatty acids & 0.6 to 6.0 \\
Phospholipids & 26 to 31 \\
\hline
\end{tabular}

The most common classes of phospholipids found in the MFGM are sphingomyelin (SM), phosphatidyl choline (PC), phosphatidyl ethanolamine (PE), phosphatidyl inositol (PI), phosphatidyl serine (PS), and lysiohosphatidyl choline. They represent 22\%, 36\%, $27 \%, 11 \%, 4 \%$, and $2 \%$ of the total phospholipids in the membrane, respectively.

The phospholipids from the membrane have been largely investigated due to their potential role in human nutrition and health. They have a wild range of actions against colon cancer, Alzheimer's disease, and support of the liver recovery from toxic attack 
(Dewettinck et al., 2008; Spitsberg, 2005). It is also known that SM and PC are important sources of choline.

\subsubsection{Method for isolating the milk fat globule membrane}

Different methods including membrane filtration, ultracentrifugation, etc. have been proposed over the years to isolate the MFGM from raw milk, but only on a laboratory scale. However, the method has been simplified and presented by Mather (2000) as a four-step procedure in which the fat globules are separated from the whole milk or buttermilk and washed several times with physiological buffers. The membrane is then released from the surface of the globules due to physical and chemicals forces and collected by centrifugation or ultracentrifugation.

First, the raw milk is skimmed using a cream separator or a centrifuge, and the cream is collected. The cream still contains proteins, lactose and minerals and need to be washed with a saline buffer in order to remove these constituents. The washing of the cream has been extensively studied and a large range of conditions has been proposed. Table 2.9 summarized some of the most common ones (Dewettinck et al., 2008). Then, the washed cream is destabilized either by churning, cycles of freezing-thawing, addition of detergent (Triton X100), sonication, or polar aprotic solvents (i.e. dimethyl formamide) (Dapper et al., 1987). Finally, an ultracentrifugation step $(100,000 \mathrm{~g}$ for 60 to 90 minutes $)$ is employed to recover the MFGM fragments (Patton and Keenan, 1975). The pellet can be frozen until further experiments. 
Table 2.9. Examples of the proposed conditions for the washing of the cream for isolation of MFGM from whole milk (row 1) and buttermilk (row 2-3) (Dewettinck et al., 2008)

Washing conditions $\quad$ Solution used $\quad$ References

Hydration for an hour at room temperature SMUF (10 volumes)

(Ye et al., 2002)

+ Centrifugation $\left(15,000 \mathrm{~g} / 20 \mathrm{~min} / 20^{\circ} \mathrm{C}\right) \quad 2$ times

*Overnight stirring at $4^{\circ} \mathrm{C}+2 \%(\mathrm{w} / \mathrm{v})$ trisodium (Corredig and

Centrifugation $\left(100,000 \mathrm{~g} / 50 \mathrm{~min} / 15^{\circ} \mathrm{C}\right) \quad$ citrate Dalgleish, 1997)

*Overnight stirring at $4^{\circ} \mathrm{C}+2 \%(\mathrm{w} / \mathrm{v})$ sodium (Morin et al., 2007)

Centrifugation $\left(50,000 \mathrm{~g} / 120 \mathrm{~min} / 4^{\circ} \mathrm{C}\right) \quad$ citrate

*from cream or buttermilk

The separation of membrane material from buttermilk is more problematic due to the fact that MFGM fragments are already present in buttermilk along with skim milk material (caseins, whey proteins). As shown in Table 2.9, isolation of MFGM fragments from cream or buttermilk required addition of sodium citrate in order to destabilize the casein micelles. The caseins then remain in the supernatant after ultracentrifugation.

\subsection{Separation and processing of milk fat}

The fat fraction of the milk naturally separates from the aqueous phase (skim milk) if the milk is standing for over 30 minutes in cool place. This phenomenon is usually named “creaming" and is attributed to the gravity separation. In fact, milk fat globules are 
lighter than the plasma phase, and hence rise to form a cream layer (O'Mahony, 1988). The rate of rise of spherical particles in a liquid (V) can be estimated using Stokes' Law:

$$
\mathrm{V}=\frac{\left(\mathrm{r}^{2}\left(\mathrm{~d}_{1} \times \mathrm{d}_{2}\right) \mathrm{g}\right)}{\mathrm{g}_{\eta}}
$$

Where, $r$ is the radius of fat globules; $d_{1}$ is the density of the liquid phase; $d_{2}$ is the density of the sphere; $g$ is the acceleration due to gravity; and $\eta$ is the specific viscosity of the liquid phase.

Gravity separation is however, slow, inefficient, and hard to reproduce even if Ma and Barbano (2000) demonstrated that the content of fat in raw milk could be reduced to $0.5 \%$ after 24 hours of standing at $4^{\circ} \mathrm{C}$.

\subsubsection{Centrifugal separation (principle, equipment, and products generated)}

In opposition to gravity separation, centrifugal separation is quicker and more efficient. Generally, the concentration of fat in skimmed milk is less that $0.1 \%$ after centrifugal separation (O'Mahony, 1988). Moreover, the centrifugal force is between 5,000 to 10,000 times greater than the gravitational force. In consequence, this process is widely used in the dairy industry and different models have been developed. Centrifugal separation is based on the fact that "when liquids of different specific gravities revolve around the same center at the same distance with the same angular-velocity, a greater centrifugal force is exerted on the heavier liquid that on the lighter one" (O'Mahony, 1988). This principle is applied to milk where the two liquids of different gravities are 
the serum and the fat. The most common type of centrifugal separator is presented in Figure 2.5.

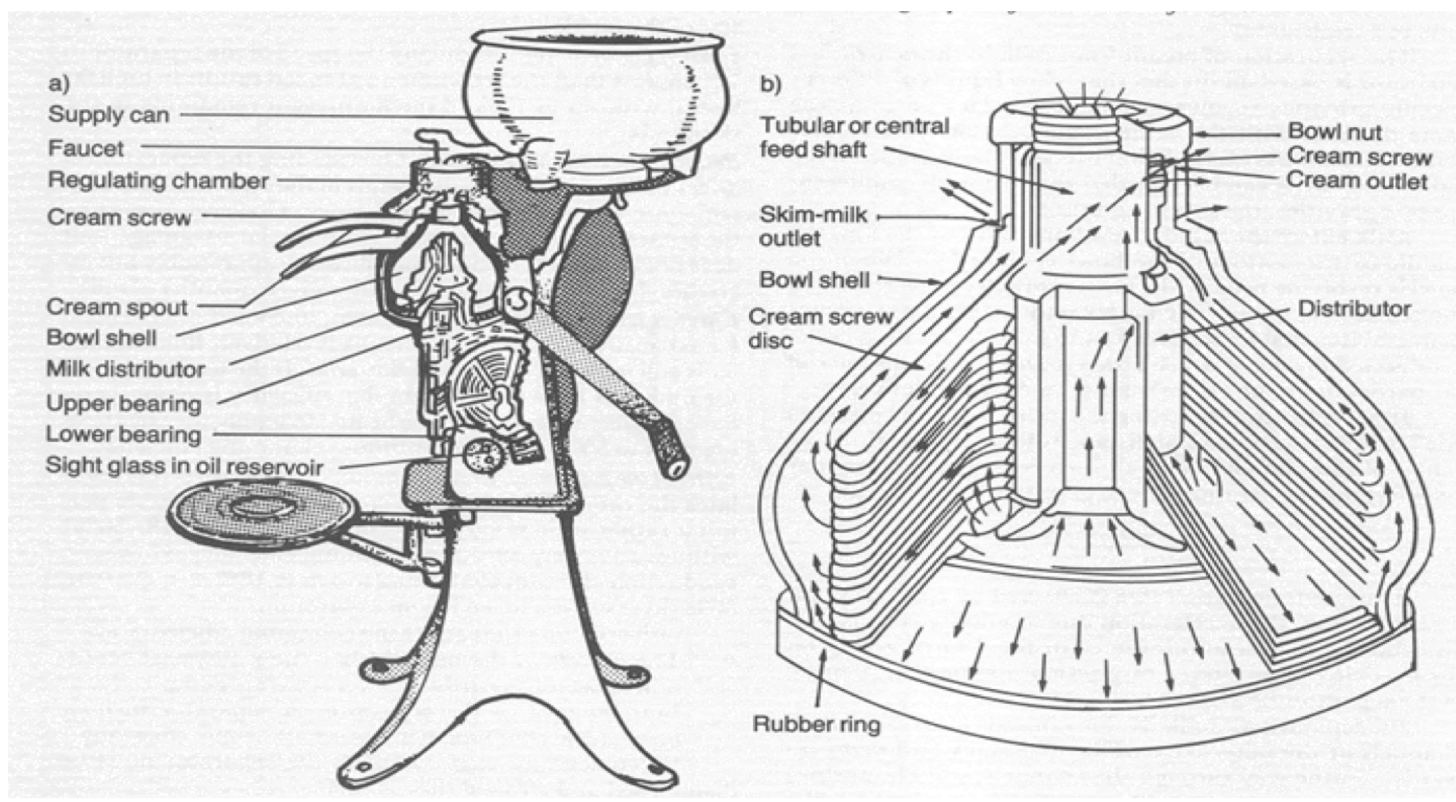

Figure 2.5. Cutaway diagram of a centrifugal separator (a) and the bowl (b). The paths of milk and cream fractions can be observed (O'Mahony, 1988).

As shown in the Figure 2.5, the milk enters in the system by the bowl, and then in the rotating vessel. There, the whole milk is introduced into separation channels at the outer edge of the disc stack and flows inwards. On the way through the channels, solid impurities are separated from the milk and thrown back along the undersides of the discs to the periphery of the separator bowl, where they are collected in the sediment space. As the milk passes along the full radial width of the discs, the time passage allows even small particles to be separated. The cream is less dense that the skim milk and therefore settles inwards in the channels towards the axis of rotation and passes to an axial outlet. The skim milk moves outwards to the space outside the disc stack and then through a 
channel between the top of the disc stack and the conical hood of the separator bowl (O'Mahony, 1988).

The efficiency of the separation of the fat from the aqueous phase depends on the speed of the bowl, the residence time in the bowl, the density differential between the fat and the liquid phase, and the size of the fat globules (O'Mahony, 1988).

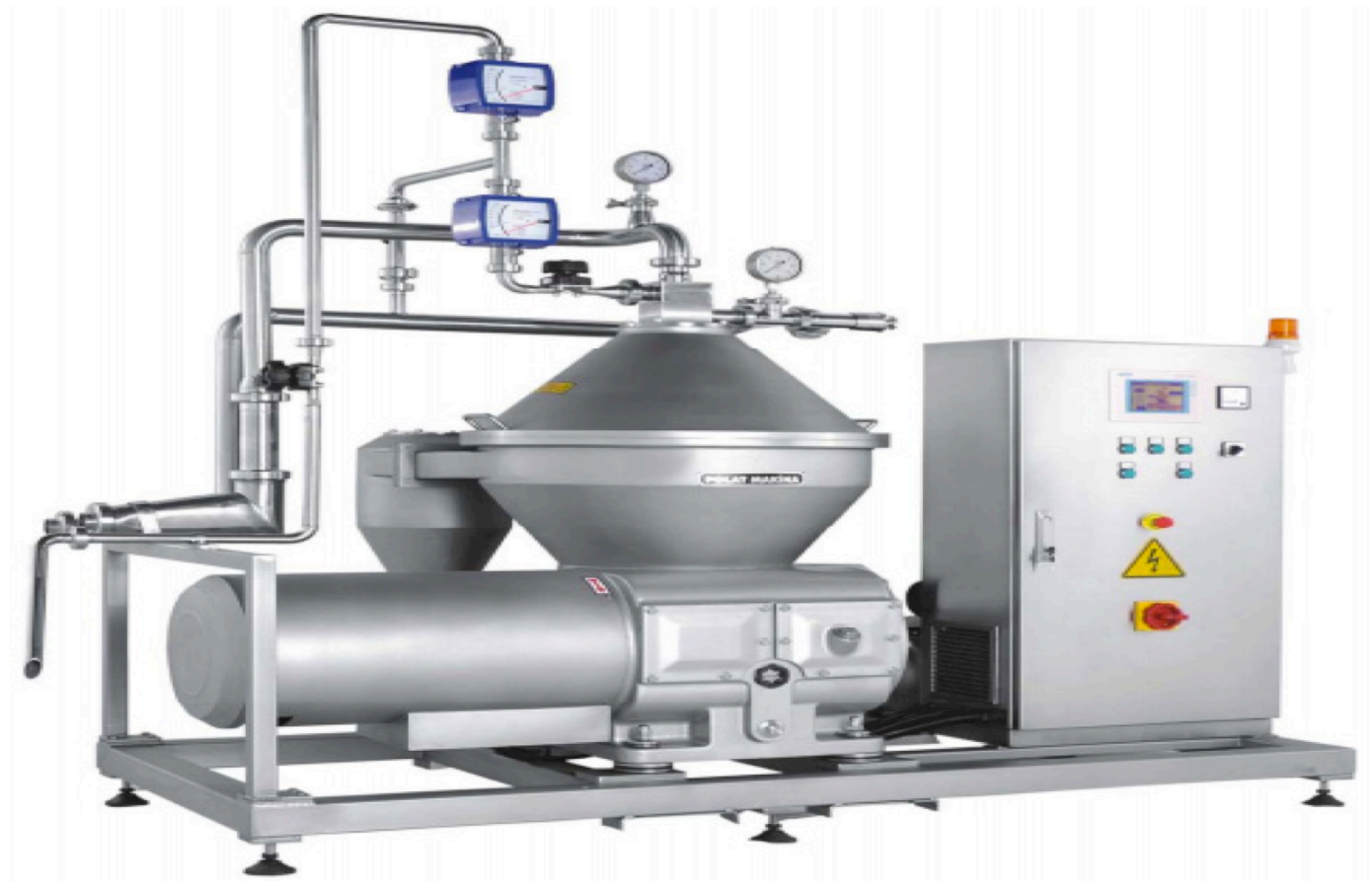

Figure 2.6. Example of an industrial milk fat separator.

\subsubsection{Phase inversion and butter-making}

After centrifugal separation, the collected cream selected for butter-making is generally standardized to 35 to $40 \%$ fat, and then pasteurized ( 90 to $110^{\circ} \mathrm{C}$ for 15 to 20 seconds) in order to destroy pathogenic microorganisms, lipases and oxydoreductases. 
The pasteurized cream is then subject to ripening (or maturation) to destabilize the fat globule. A physical ripening aims to manage the milk fat crystallization to reduce lipid losses during churning and to shape the butter texture (leads to sweet buttermilk, also called commercial buttermilk) (Vanderghem et al., 2010). Biological ripening consists of the addition of ferments to the cream (Lactococcus lactis subsp. cremonis and Lactococcus lactis biovar.) to lower acidity and develop butyric aromas (leads to cultured buttermilk). A whey cream can be obtained by skimming whey from cheese making (leads to whey buttermilk). This product is richer in MFGM materials and contains only residual caseins.

However, complete destabilization of the cream is obtained by mechanical churning that consists of the reversion of an oil-in-water emulsion into a water-in-oil emulsion. As air is incorporated during the churning, proteins ( $\beta$-lactoglobulin, $\alpha$-lactalbumin, and $\beta$ casein) from the cream unfold and form unstable foam with the air bubbles. Upon mechanical stress, the foam is destabilized, resulting of fat clumping and phase inversion. Butter becomes solid while the water and soluble particles form the buttermilk (Boudreau and St-Amant, 1984). The formation of butter is represented in Figure 2.7.

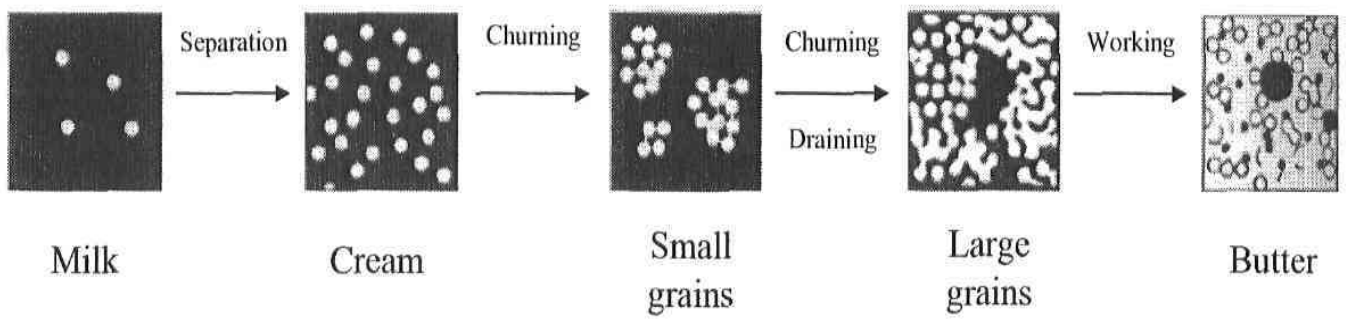

Figure 2.7. The different stages of the formation of butter adapted from Mulder and Walstra (1974). The fat is represented in white and the serum in black. 
Over the decades, the technological process of butter making has progressed from discontinuous agitation in farm churns to continuous churning processes as represented in Figure 2.8.

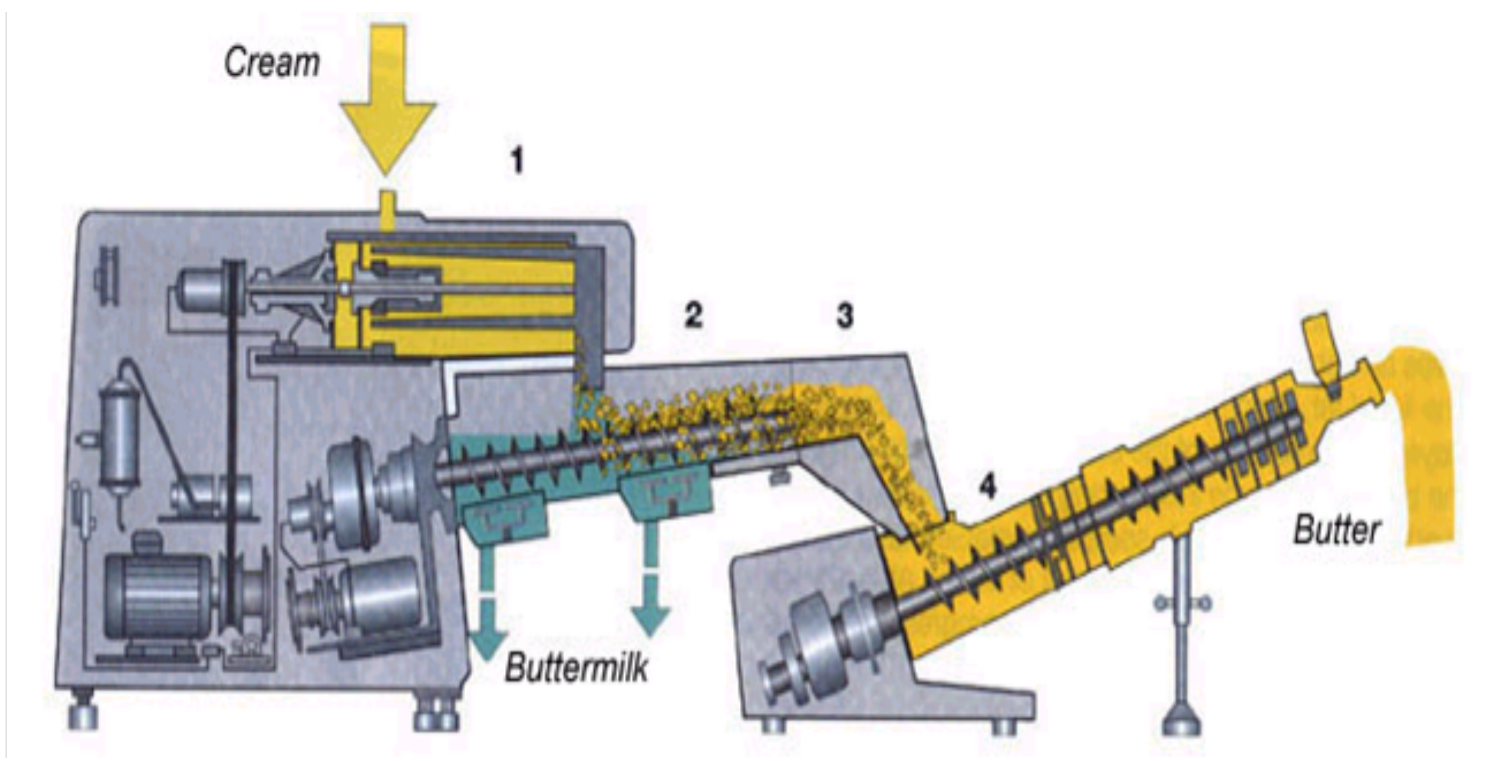

Figure 2.8. Example of a continuous butter churn from (Bylung, 1995). 1 corresponds to a variablespeed motor; 2 to separation section; 3 to a squeeze-drying section; 4 to a second working section; 5 to a high-pressure injector (for salt).

\subsubsection{Buttermilk composition, properties and utilization}

Buttermilk is the aqueous phase resulting from the butter-making process, so it recovers most of the protein, minerals, lactose and water from the cream. High portions of the MFGM fragments (proteins + phospholipids) are also present in the buttermilk. As shown in Table 2.10, the composition of buttermilk is often judged close to the composition of skim milk. The proteins present in buttermilk are mostly caseins $(\sim 75 \%$ 
of total proteins), whey proteins (8 to $15 \%$ of total proteins), and MFGM proteins (Sodini et al., 2006). The compositions of sweet and cultured buttermilk are comparable, however, the composition of whey buttermilk is more close to the composition of whey but with a higher fat content (Sodini et al., 2006).

Table 2.10. Comparison between the gross composition of buttermilk and skim milk (Ramachandra Rao et al., 1995; Walstra et al., 2006).

\begin{tabular}{lrc}
\hline Constituents & Buttermilk & Skim Milk \\
\hline Total solids (\%) & 9.50 to 10.50 & 9.40 \\
Lactose (\%) & 3.60 to 4.30 & 4.80 \\
Proteins (\%) & 3.30 to 3.90 & 3.36 \\
Fat (5) & 0.30 to 0.70 & 0.07 \\
Phospholipids (\%) & $\mathbf{0 . 0 7}$ to $\mathbf{0 . 1 8}$ & $\mathbf{0 . 0 1 5}$ \\
Ash (\%) & 0.55 to 0.90 & 0.88 \\
\hline
\end{tabular}

Buttermilk is prone to oxidation, so it has to be concentrated by evaporation and spraydried quickly after production to extent the shelf life. Currently, dried buttermilk is mainly use for animal feeding.

Due to the high proportion of protein and phospholipids, buttermilk shows interesting foaming and emulsification properties. For example, different potential applications such 
as emulsification agent in oil-in -water emulsions, cheddar or mozzarella cheese with reduced fat have been proposed over the years and studied by Vanderghem et al. (2010). Other potential applications have also been proposed such as moisture retention in pizza cheese or bread or reduced-fat cheddar cheese, texture agent in low-fat mozzarella cheese or low fat yogurts, flavor agent in cheddar cheese or recombined cream, etc. Unfortunately, buttermilk has not found many industrial applications yet. One of the reason is that the exploitation of buttermilk constituents is complicated due to some irreversible changes that appear along the process such as the solubility of the MFGM proteins at $\mathrm{pH} 4.6$, the reactivity of the surface of the fat membrane, the poor coagulation properties of caseins from buttermilk and the accessibility of phospholipids (increased) that could be related to high moisture retention (Morin, 2006).

Despite all, recent studies showed that whey buttermilk could be a very promising ingredient for food development due to the absence of caseins and the higher phospholipid to protein ratio (Costa et al., 2010; Sodini et al., 2006). Whey buttermilk shows higher emulsification properties and lower foaming ability compared with sweet or cultured buttermilk, and stable levels of protein solubility, emulsifying capacity and viscosity at $\mathrm{pH}$ ranged from 4.0 to 6.0 .

Furthermore, buttermilk is rich in minor components such as MFGM and associated material that have show very promising health properties ranging from anti-viral to anticancer, including Alzheimer disease (Dewettinck et al., 2008). Unfortunately, the separation of the MFGM material from buttermilk is very challenging due to the size 
similarity with casein micelles (Morin, 2006). However, they demonstrated that the separation could be improved with the addition of a cream-washing step prior to the microfiltration. Moreover, (Costa et al., 2010) proposed an approach to produce buttermilk powder containing $73 \%$ of proteins ( $\%$ of total solids) and $21 \%$ of lipids ( $\%$ of total solids) of which $61 \%$ where phospholipids using whey buttermilk and $\mathrm{CO}_{2}$ supercritical fluid extraction.

\subsection{Interactions between casein micelles and other milk components}

Proteins generally tend to aggregate (or interact) under a variety of environmental conditions through three main pathways such as: 1) aggregation through unfolding intermediates and unfolded states, 2) aggregation through protein self-association or chemical linkages, and 3) aggregation through chemical degradations (Wang et al., 2010). The extent of aggregation depends on intrinsic factors like the structure of the protein (primary, secondary, tertiary, or quaternary) or extrinsic factors such as the environment of the proteins or the processing conditions. Aggregated proteins may present less desirable characteristics like the poor coagulation properties of the casein from buttermilk.

\subsubsection{Whey proteins}

Interactions between casein micelles and whey proteins have been extensively studied starting a systematic series of studies since 1963 (Sawyer et al., 1963) and these studies have dealt with mainly heat-induced interactions. However, very limited information is available for physical and shear interactions. 
During heating, the free thiol group (-SH) of $\beta$-Lactoglobulin ( $\beta-\mathrm{LG})$ and Bovine Serum Albumin (BSA) are exposed at $78.5^{\circ} \mathrm{C}$ and $\sim 70^{\circ} \mathrm{C}$ respectively (Gezimati et al., 1996; Havea et al., 2000; Schokker et al., 1999). These free thiol groups initiate the formation of thiol/disulfide interactions (SH/SS) with the $x$-casein located at the surface of the casein micelles as simplified in Figure 2.9 (Donato et al., 2007; Sawyer, 1968; Vasbinder et al., 2003). In their study, Livney and Dalgleish (2004) observed the formation of disulfide bonds between the residues $\mathrm{Cys}_{66}$ of $\beta$-LG and $\mathrm{Cys}_{11}$ of $\chi$-casein and between $\mathrm{Cys}_{160}$ of $\beta-\mathrm{LG}$ and $\mathrm{Cys}_{88}$ of $\boldsymbol{x}$-casein. The interactions between whey protein and casein micelles are defined as temperature and $\mathrm{pH}$ dependent. For example, in their study Smits and van Brouwershaven (1980) reported that $83 \%$ of the total $\beta-\mathrm{LG}$ in skim milk was associated with the casein micelle at $90^{\circ} \mathrm{C}$ at $\mathrm{pH} 5.8$ while the amount decreased to $76 \%$, $44 \%$, and $24 \%$ at $\mathrm{pH}$ 6.6, 6.8, and 7.3, respectively. Later, Anema and Li (2003) observed an increase of the size of the micelles of 30 to $35 \mathrm{~nm}$ at $\mathrm{pH} 6.5$ while the increase was only $10 \mathrm{~nm}$ at $\mathrm{pH} 6.7$ upon light heating of skim milk. Due to its lack of free thiol group, $\alpha$-lactalbumin ( $\alpha$-LA) appears to interact with the casein micelle only after aggregation with $\beta$-LG.
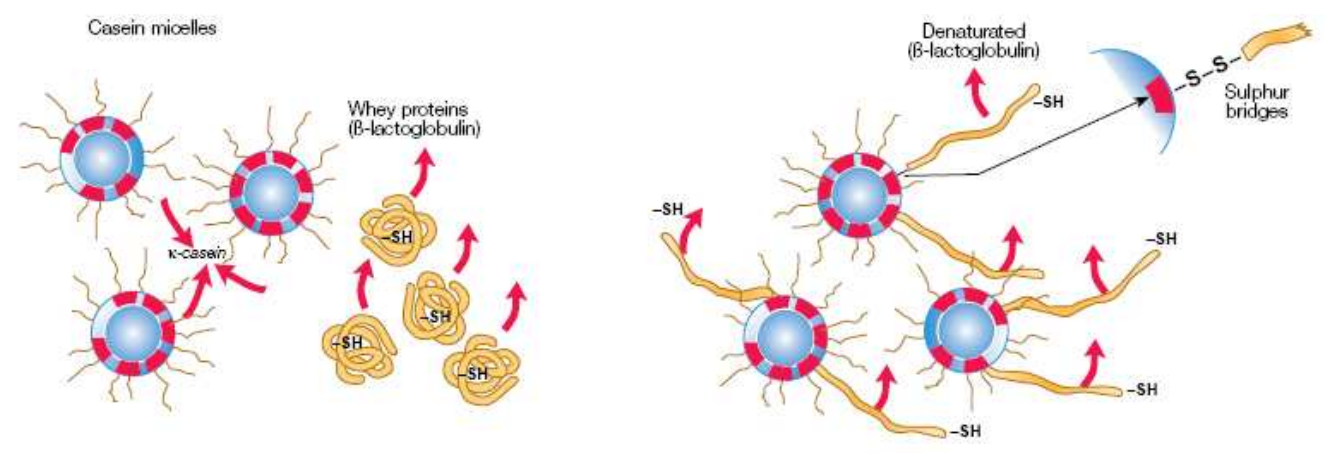

Figure 2.9: Schematic representation of the association of the casein micelle with whey proteins (Bylung, 1995). 
Despite all the evidence found during the last fifty years, the mechanism of heat-induced interaction between casein micelle and whey proteins is uncertain. It is still not clear if the whey proteins self-aggregate prior to the association with the micelle or if the whey proteins self-associate at the surface of the casein micelle (Donato and Guyomarc'h, 2009). On the other hand, it is clear that the $x$-casein plays an important role in the interaction with the whey proteins, but there are still questions remaining such as when the $x$-casein dissociate from the micelle.

The understanding of the association of whey proteins with the casein micelle during processing is important because it will help to limit possible irregularities in the production of cheese or help to better use dairy by-products such as buttermilk.

\subsubsection{Other minor components}

Interactions of the MFGM proteins with other milk proteins have not been fully understood yet. So far, it is known that some of the MFGM protein such as XO, BTN, PAS 6 can interact with each other under heating and at low temperatures $\left(\sim 60^{\circ} \mathrm{C}\right)$ (Appel et al., 1982; Ye et al., 2002). Later, (Ye et al., 2004b; Ye et al., 2004c) proposed mechanisms of heat-induced association of whey proteins with MFGM proteins where the interactions are initiated by the free thiol groups of the MFGM proteins and the complex is stabilized by $\mathrm{SH} / \mathrm{SS}$ exchanges with the whey proteins. For example, $\mathrm{XO}$ has 38 free thiol groups with 4 available in the native form of the protein (Cheng et al., 1988). 
Even if there is not much proof of interactions of MFGM proteins with the casein micelle, it is easy to hypothesize that the MFGM proteins can initiate interactions with $x$ casein through their free thiols as $\beta$-lactoglobulin does. Houlihan et al. (1992) concluded that $x$-casein may interact directly with MFGM components and that the interactions increased with time. Later, Corredig and Dalgleish (1996a) found that some casein were present in fat globule isolates only after heating whole milk by direct steam injection. Their result suggests that the interactions are strong due to the isolation method (urea treatment). However, these studies do not permit to conclude if it is individual caseins or the casein micelles that interact with the MFGM proteins. However, Ye et al. (2004c) reported the presence of $x$-casein and other caseins in the MFGM material. These observations strongly suggest that the casein micelles associate with the MFGM via SH/SS exchanges between $\varkappa$-casein and MFGM proteins.

Association between the casein micelles and the MFGM proteins does not only appear under heating. Ye et al. (2004a) showed that caseins also appear to interact with the caseins under high pressures through SH/SS exchange between $x$-casein and the MFGM proteins. Needs et al. (2000) concluded that high pressures (250 to $600 \mathrm{MPa}$ ) disrupted the micelles into smaller fragments that are likely to be absorbed at the surface of the fat globules.

Houlihan et al. (1992) proposed that the milk proteins could associate with the MFGM material through the membrane lipids. During processing, the MFGM proteins may be lost while the hydrophobic regions of the membrane phospholipids become more 
accessible. Morin (2006) showed that buttermaking process modifies the surface of the fat membrane and increase the accessibility of phospholipids. More recently, Saffon (2013) showed that protein aggregates were formed during processing of buttermilk including caseins, whey proteins, MFGM proteins, and phospholipids.

\subsubsection{Fatty acids and other lipids}

According to Barratt et al. (1974), interactions between proteins and lipids are possible in a "water-based" mixture if the free energy lost by the protein is greater than the free energy lost by its association with the lipid. As a general trend, the association is initiated by ionic interaction between charged amino acid residues in the protein (lysine or arginine) and the polar head groups (phosphate or carboxylic) of the lipid to position the lipid. Then, the complex is stabilized by hydrophobic interactions between the hydrophobic side of the protein and the hydrocarbon chain of the lipid (Dufourcq and Faucon, 1977; Ong et al., 1981).

Barratt et al. (1974) demonstrated that $\alpha_{\mathrm{S} 1}$-casein was able to interact with synthetic lecithins and lysolecithins in their system while $\beta$-casein and $x$-casein were not found to interact with the phospholipids. Their results showed that long-chain lipids formed stable lipid-protein complex while the short-chain lipids formed were not stable. Overall, Barratt et al. (1974) found $\alpha_{\mathrm{S1}}$-casein could bond with 30 to 35 molecules phospholipids (lysolecithin in that case). 


\section{MATERIALS AND METHODS}

\subsection{Materials}

Raw whole fresh milk and fresh cream were collected from the bulk of a local dairy (Natrel, Quebec City, QC, Canada). Reactants for the polyacrylamide gel electrophoresis techniques were from Bio-Rad (Bio-Rad laboratories Ltd., Hercules, CA, USA) and all other reagents were from Fisher Scientific (Fair Lawn, NJ, USA).

\subsection{Preparation of raw cream, raw skim milk and raw buttermilk}

After the addition of $0.02 \%$ sodium azide $(\mathrm{w} / \mathrm{v})$, the raw milk was skimmed at $10^{\circ} \mathrm{C}$ by centrifuging at $2400 \mathrm{x}$ g for 20 minutes in a $5804 \mathrm{R}$ Eppendorf preparative centrifuge with A-4-44 rotor (Eppendorf, 5894R Westbury, NY, USA). The raw skimmed milk was collected and approximately $250 \mathrm{~mL}$ of fresh cream was taken from stock prior to churning.

A total volume of $5 \mathrm{~L}$ of raw cream was churned in a rotary churn at $30 \mathrm{rpm}$ and $18^{\circ} \mathrm{C}$ and was broken down within an average of 30 minutes of churning. The buttermilk was recovered from the churn in a stainless steel panel, and butter was discarded.

Samples of cream, skim milk, and buttermilk were stored at $4{ }^{\circ} \mathrm{C}$ overnight. The overall process used for the preparation of the ingredients is summarized in Figure 3.1. 


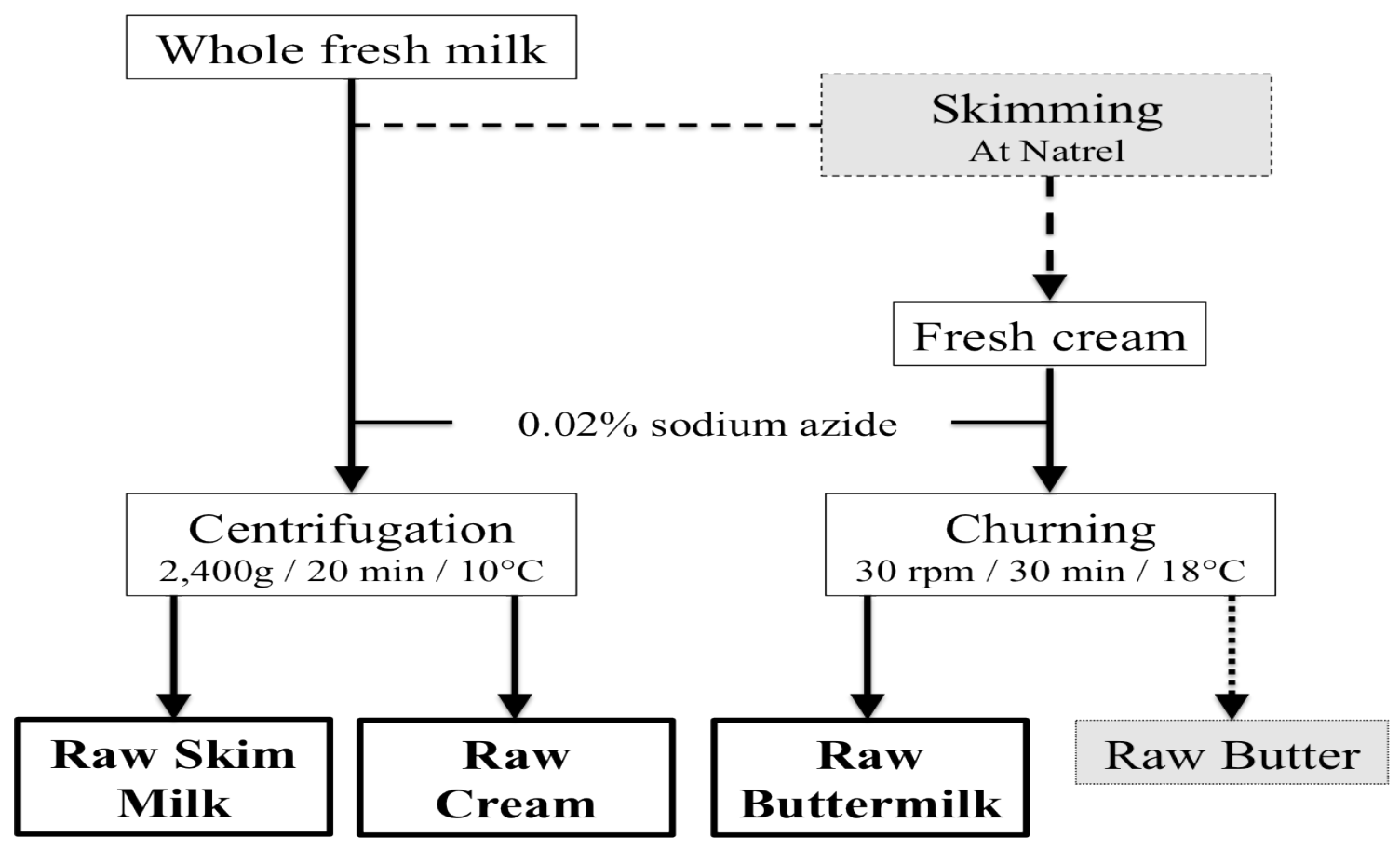

Figure 3.1: Experimental procedure used to prepare the raw cream, raw skim milk, and raw buttermilk

\subsection{Isolation of casein micelles}

Casein micelles were separated from raw cream, skim milk, and buttermilk according to the method described by Corredig and Dalgleish (1996b) using a Beckman preparative ultracentrifuge (L8-M, rotor 50.Ti) at $60000 \mathrm{x}$ g for 40 minutes at $25^{\circ} \mathrm{C}$. The supernatant was decanted and the micellar pellet was resuspended in buffer $\mathrm{pH} 7.0$, containing $20 \mathrm{mM}$ imidazole, $5 \mathrm{mM} \mathrm{CaCl}_{2}$, and $50 \mathrm{mM} \mathrm{NaCl}$. After a second ultracentrifugation under the same conditions, the micellar pellet was collected, drained on Whatman No. 1 filter paper, and frozen until further analysis under the following names: SM, CR, and BM for the casein micelles of raw skim milk, cream, and buttermilk, respectively. The overall process for the isolation of the casein micelles is summarized in Figure 3.2. 


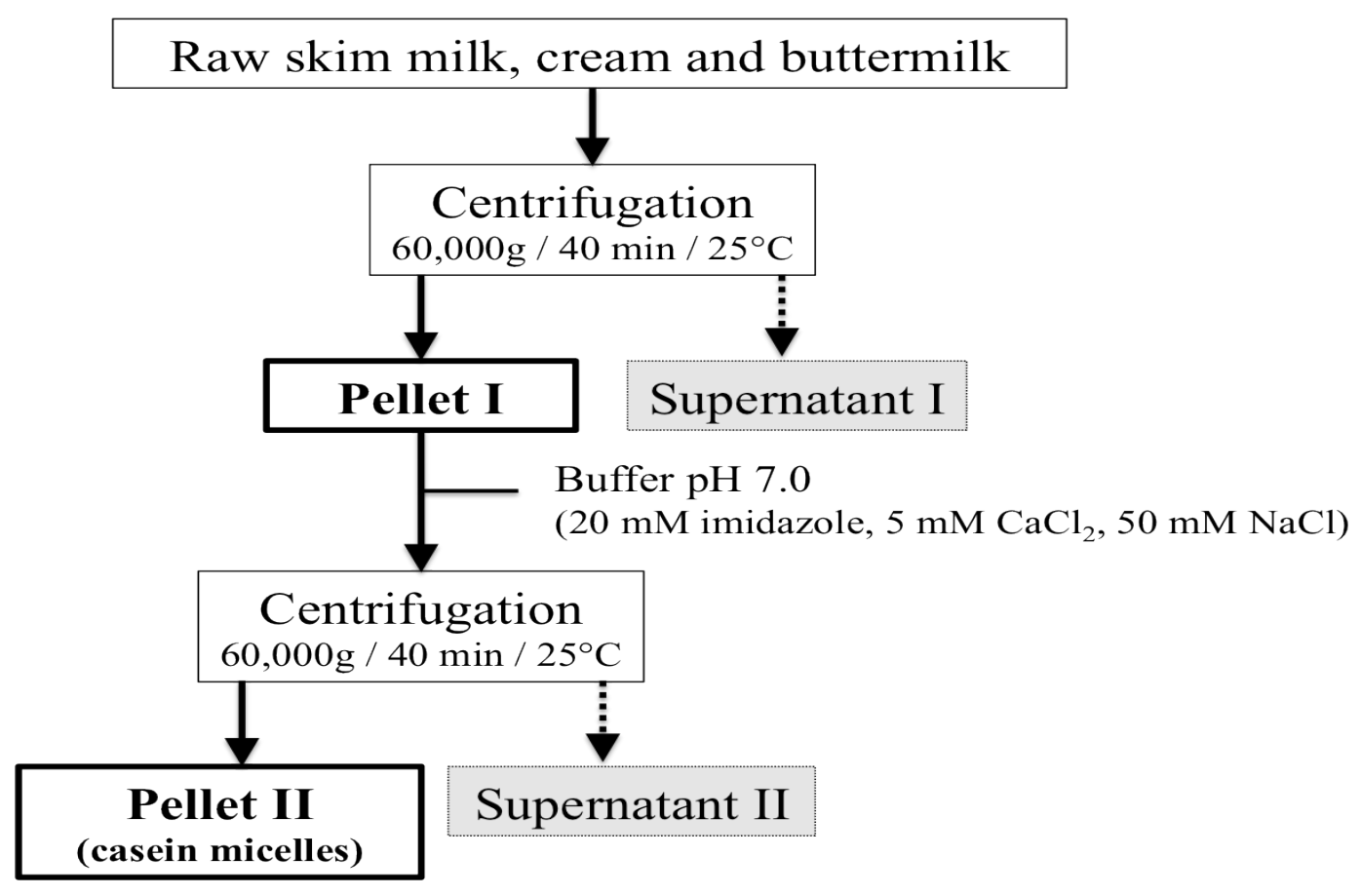

Figure 3.2: Experimental procedure used to isolate the casein micelles from the raw cream, raw skim milk, and raw buttermilk.

\subsection{Analytical methods}

\subsubsection{Composition}

Total protein in raw, supernatant, and micellar sample was determined by measuring total nitrogen using the Dumas combustion method (LECO TruSpec N analyzer, LECO, St. Joseph, MI) (IDF, 2002), and converting the value to protein using a conversion factor of 6.38. Total solids were obtained by microwave drying for 4 hours at $102^{\circ} \mathrm{C}$ (Fisher Scientific, Isotemp vacuum oven, model 280A). The lipid content was obtained gravimetrically using the Mojonnier extraction method (IDF, 2008). 


\subsubsection{Polyacrylamide gel electrophoresis}

\subsubsection{One-dimensional PAGE}

The analyses were performed according to the method described by Laemmli (1970). A weighed amount of the ultracentrifuged micellar fraction (about $15 \mathrm{mg}$ ) was resuspended in $10 \mathrm{~mL}$ of deionized water and vortexed. Next, $10 \mu \mathrm{L}$ of the solution was mixed with $20 \mu \mathrm{L}$ of a solution of $95 \%$ Laemmli buffer (Bio-Rad Laboratories Ltd.) and 5\% 2mercaptoethanol. Supernatant fractions were diluted 4:1 with Laemmli buffer and 2mercaptoethanol. All samples were vortexed and boiled for 5 minutes in a water bath. Aliquots $(10 \mu \mathrm{L})$ of denatured protein samples were loaded onto hand cast $12.5 \%$ TrisHCL polyacrylamide gels. Electrophoresis was conducted using a Mini Protean® II gel kit (Bio-Rad) at 90V for approximately 60 minutes, in 5X SDS-PAGE running buffer containing Tris, glycine, and SDS. Following electrophoresis, gels were stained in Coomassie blue (50\% methanol, $10 \%$ glacial acetic acid and $0.25 \%$ Coomassie brilliant blue), overnight on a shaker plate at room temperature. Subsequently, gels were destained in a $80 \%$ deionized water, $10 \%$ methanol, and $10 \%$ glacial acetic acid solution for two hours. Gels were then photographed using a Bio-Rad ChemiDoc.

\subsubsection{Two-dimensional PAGE}

The sample preparation for 2D electrophoresis was adapted from the method of Fortunato et al. (2003) with minor modifications. Briefly, casein micellar pellets (250 $\mu \mathrm{g})$ were solubilized in $250 \mu \mathrm{L}$ of deionized water, and were then precipitated and defatted with $1 \mathrm{~mL}$ of methanol, chloroform, and deionized water in a ratio of 500:125:375 (v:v:v). Suspensions were then centrifuged at $10,000 \mathrm{xg}$ for $10 \mathrm{~min}$. The upper layer was removed and $500 \mu \mathrm{L}$ of 
methanol was added to the lower layer. Suspensions were centrifuged at $10,000 \mathrm{xg}$ for 10 min and pellets were dried by evaporation of solvents. The pellets were then solubilized in $250 \mu \mathrm{L}$ of an electrophoretic sample buffer consisting of $7 \mathrm{M}$ urea, $2 \mathrm{M}$ thiourea, $4 \%$ (w/v) CHAPS, $1 \%$ (v/v) Triton-X-100, 20 mM Tris, 0.5\% (v/v) IPG buffer pH 3-10 (Amersham Biosciences, Baie d'Urfé, Quebec, Canada), and $60 \mathrm{mM}$ dithiothreitol (DTT) (Sigma-Aldrich, Oakville, Ontario, Canada). Approximately $250 \mu \mathrm{g}$ of protein was loaded onto an $18 \mathrm{~cm} \mathrm{pH} \mathrm{3-10} \mathrm{immobilized} \mathrm{pH} \mathrm{gradient} \mathrm{(IPG)} \mathrm{strip} \mathrm{(GE} \mathrm{Healthcare)} \mathrm{and}$ was actively rehydrated over $18 \mathrm{~h}$ using a Step-n-hold setting. The rehydrated IPG strips were focused in an IPGphor (Amersham Pharmacia Biotech) at 30V for 12 hours, followed by 1 hour at $100 \mathrm{~V}, 1$ hour at $500 \mathrm{~V}, 1$ hour at $1000 \mathrm{~V}, 1$ hour at $5000 \mathrm{~V}$ and 2 hours at $8000 \mathrm{~V}$ to achieve a total of $16000 \mathrm{Vh}$. The focused IPG strips were equilibrated with a $2 \%$ sodium dodecyl sulfate (SDS) buffer containing $1 \%$ DTT, $50 \mathrm{mM}$ Tris-HCl, $30 \%$ glycerol and 6M Urea for 15 minutes. The focused and equilibrated IPG strips were embedded with $0.5 \%$ agarose on top of a 5-15\% Tris-HCl SDS-polyacrylamide gel electrophoresis (PAGE) gel. Electrophoresis was performed on a Protean II electrophoresis unit (BioRad) at a constant current per gel of $25 \mathrm{~mA}$ for 20 minutes followed by $30 \mathrm{~mA}$ for approximately 4 hours, until the bromophenol blue dye front reached the bottom edge of the gel. Proteins were fixed on the gel overnight in a fixation solution containing 50\% ACS Methanol, 40\% deionized water, and 10\% glacial acetic acid. The next morning, the fixation solution was replaced for one hour, and the gel was rinsed with deionized water before the addition of Gel CodeBlue stain overnight. Finally, the gel was washed for 2 hours before imaging on a BioRad ChemiDoc. 
The milk fat globule membrane proteins (MFGM proteins) were separated from the pellet II fraction of the samples, as proposed by Corredig and Dalgleish (1997). Briefly, the pellets were dispersed in a sodium citrate buffer $(5 \% \mathrm{w} / \mathrm{v})$ and stirred overnight. The solutions were centrifuged for 2 hours at $50,000 \mathrm{~g}$ at $4^{\circ} \mathrm{C}$, the supernatant was discarded, and the pellet was dispersed in a PBS buffer (containing 1\% (w/v) of Triton X-100). The solutions were centrifuged for 2 hours at $50,000 \mathrm{~g}$ at $4^{\circ} \mathrm{C}$, the supernatant was discarded, and the pellet was drained on Whatman No. 1 filter paper with $25 \mathrm{~mL}$ of deionized water. Finally, the pellet was dispersed in $25 \mathrm{~mL}$ of deionized water. The protein profile was determined using the two-dimensional PAGE procedure described above.

\subsubsection{Particle size distribution and zeta potential of the casein micelles}

Particle size and zeta potential measurements were made by photon correlation spectroscopy using a Malvern Zetasizer 4 instrument and a glass cuvette with round top particle sizing cell (Malvern Instruments Ltd, Worcestershire, UK) (Malvern Instrument SA, 2009). A weighed amount of the ultracentrifuged micellar fraction (about $0.02 \mathrm{~g}$ ) was resuspended in $10 \mathrm{~mL}$ of deionized water using a stir plate overnight at $4^{\circ} \mathrm{C}$. The temperature of the cell was maintained at $25 \pm 0.5^{\circ} \mathrm{C}$ for the duration of the experiments. Each sample had a total of 5 measurements. Measurements of the dynamics of the scattered light were collected at a $173^{\circ}$ scattering angle. The rates of change of intensity of light were translated into average particle diameters using the Stokes-Einstein relationship for spheres. 
A weighed amount of the ultracentrifuged micellar fraction (about 0.02g) was resuspended in $10 \mathrm{~mL}$ of deionized water using a stir plate overnight at $4^{\circ} \mathrm{C}$. Each measurement was performed at $25^{\circ} \mathrm{C}$ the following morning using a universal dip cell. Each sample was measured a total of 5 times.

The Zetasizer software calculates the electrophoretic mobility by measuring the speed of movement of the charges through the application of electric current particles. The zeta potential is then estimated from the electrophoretic mobility by the Henry equation:

$$
z=\frac{3 U_{E} \eta}{2 \varepsilon f(\kappa a)}
$$

Where,

$\mathrm{Z}=$ zeta potential

$\mathrm{U}_{\mathrm{E}}=$ electrophoretic mobility

$\boldsymbol{\eta}=$ viscosity of the solution

$\boldsymbol{\varepsilon}=$ dielectric constant

$f(x a)=$ function of Henry. The term $x$ a measures the ratio between the radius of the particle and the thickness of the double electric layer (Debye layer).

\subsubsection{Phosphorus content of micellar pellet}

Phosphorus determinations were performed colorimetrically using the method of Allen (1940). Sample preparation enabled to estimate all the forms of phosphorus (esterified, mineral, etc.) in the pellets. (See Figure 3.3) 


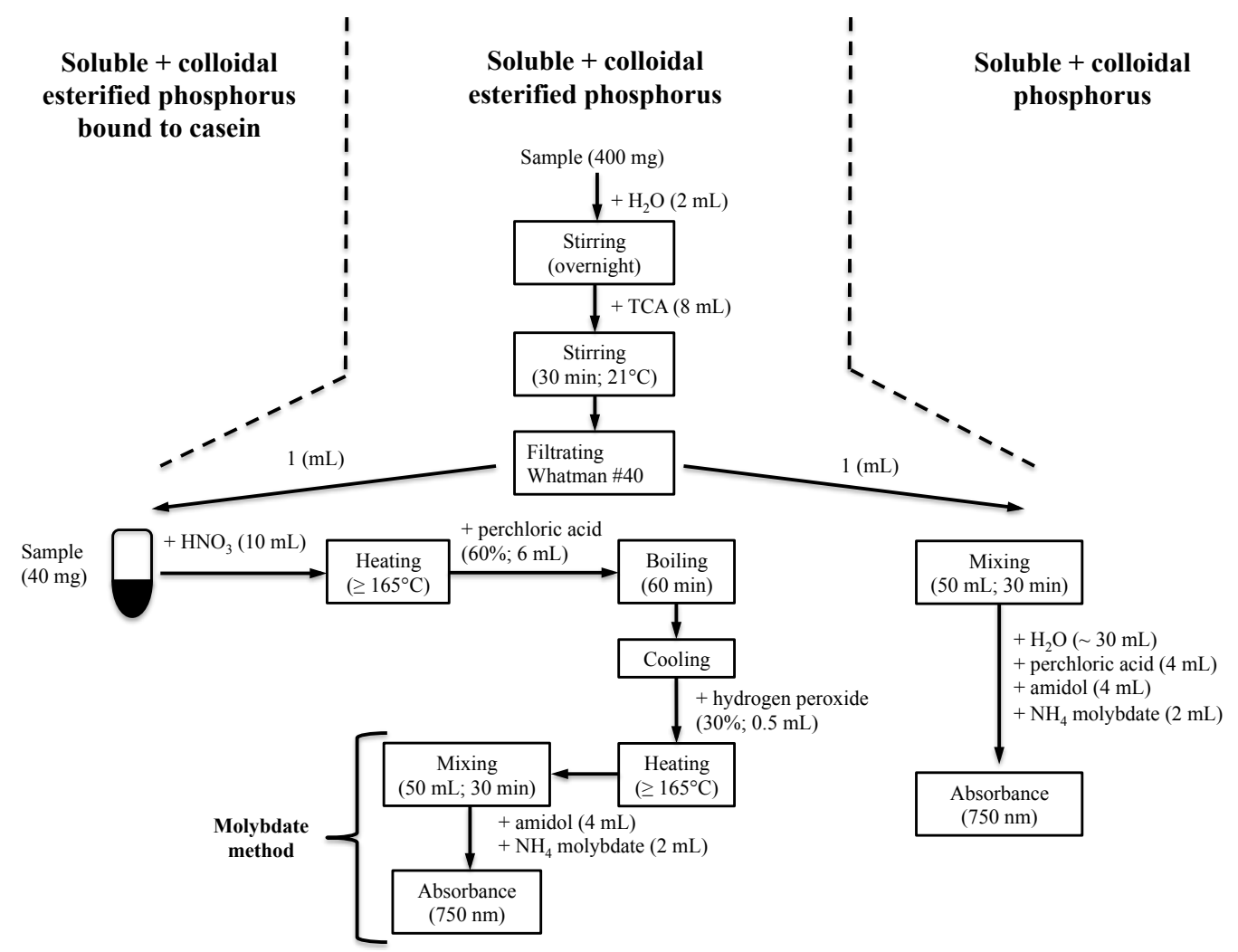

Figure 3.3: Experimental procedure used to determine phosphorus content of casein pellets.

\subsubsection{Total Phosphorus}

A sample of 40mg of micellar pellet was weighed on nitrogen-free weighing paper and was added to a micro-kjeldahl flask with glass beads and $10 \mathrm{~mL}$ of $70 \%$ Nitric acid. The tubes were heated on a heating block to $\geq 165^{\circ} \mathrm{C}$ until $2-3 \mathrm{~mL}$ of liquid remained. $6 \mathrm{~mL}$ of $60 \%$ Perchloric acid was added to the tubes, and the solution was boiled at $\geq 210^{\circ} \mathrm{C}$ for one hour or until the color changed became clear and transparent. The tubes were cooled to room temperature, and $0.5 \mathrm{~mL}$ of hydrogen peroxide was added. After, the tubes were heated slowly to $\geq 165^{\circ} \mathrm{C}$ until all chloride and peroxide were removed ( $\sim 15$ minutes). The tubes were then cooled to room temperature and were washed and transferred to a 50 $\mathrm{mL}$ volumetric flask with $\sim 30 \mathrm{~mL}$ of deionized water. The molybdate method was then 
carried out by adding $4 \mathrm{~mL}$ of an amidol solution, $2 \mathrm{~mL}$ of Ammonium molybdate, and filled to the line with deionized water. Between 15 and 30 minutes after the addition of ammonium molybdate, the absorbance was read at 750nm using a spectrophotometer.

\subsubsection{Total Phosphorus acid-soluble (esterified P, soluble+colloidal P)}

Approximately $400 \mathrm{mg}$ of sample was solubilized in $2 \mathrm{~mL}$ deionized water overnight at $4^{\circ} \mathrm{C}$. The following day, the samples were transferred to a $10 \mathrm{~mL}$ volumetric flask and 8 $\mathrm{mL}$ of $10 \%$ Trichloroacetic acid (TCA) was added. The sample was mixed well and left to sit at room temperature for 30 minutes. Next, the samples were filtered on a Whatman No. 40 filter paper, allowing the first few drops to be discarded. One $\mathrm{mL}$ of the filtrate was added to a micro-Kjeldahl tube and the same digestion method was carried out as the total phosphorus. Finally, the molybdate method was then carried out by adding $4 \mathrm{~mL}$ of an amidol solution, $2 \mathrm{~mL}$ of ammonium molybdate, and filled to the line with deionized water. Between 15 and 30 minutes after the addition of ammonium molybdate, the absorbance was read at 750nm using a spectrophotometer.

\subsubsection{Acid-soluble Inorganic Phosphorus (soluble+colloidal)}

One $\mathrm{mL}$ of the filtrate from the total phosphorus acid-soluble (esterified $\mathrm{P}$, soluble+colloidal P) was added to a $50 \mathrm{~mL}$ volumetric flask immediately after filtration. To the flask was added: $30 \mathrm{~mL}$ deionized water, $4 \mathrm{~mL}$ perchloric acid, $4 \mathrm{~mL}$ amidol solution, and $2 \mathrm{~mL}$ ammonium molybdate. After 15 minutes, the absorbance of the sample was read at 750nm using a spectrophotometer. 
From the phosphate stock solution, 3 standards were made $(0.05,0.16$ and $0.3 \mathrm{mg} / 50$ $\mathrm{mL}$ ). The digestion process was completed as normal, and the required volume of the stock solution was added to the volumetric flask just before the addition of $4 \mathrm{~mL}$ perchloric acid, $4 \mathrm{~mL}$ of amidol solution, and $2 \mathrm{~mL}$ of ammonium molybdate. After 15 minutes, the absorbance of the sample was read at $750 \mathrm{~nm}$ using a spectrophotometer. A standard curve was created with the average values of the duplicate samples, and a bestfit line was added to find the slope and intercept of the line.

\subsubsection{Freeze-drying of micellar pellet}

Between 0.9 and $1.5 \mathrm{~g}$ of sample were placed in an $1.5 \mathrm{~mL}$ centrifuge tube was were frozen for 24 hours at $-80^{\circ} \mathrm{C}$. The centrifuge tubes were opened and parafilm was placed over the opening and were punctured with a sterile needle. The vacuum and refrigeration of the freeze-drying system (LABCONCO, LyphLock 4.5, Kansas City, MO, USA) was equilibrated at $-45^{\circ} \mathrm{C}$, and the samples were freeze-dried for 24 hours and placed in a desiccator until further use.

\subsection{Cation content of micellar pellet}

Sodium, Magnesium, Potassium, and Calcium content of the micellar pellet from cream, skim milk, and buttermilk were measured using atomic absorption methods of Brooks et al. (1970). 


\subsubsection{Total Calcium (Ca), Potassium (K), Sodium (Na), and Magnesium (Mg)}

Approximately $100 \mathrm{mg}$ of freeze-dried micellar pellet was placed in a pre-conditioned crucible. The crucible was then ashed overnight $(\sim 18$ hours $)$ at $550^{\circ} \mathrm{C}$. The following morning, the sample was weighed and the ashes were dissolved in $1 \mathrm{~mL}$ of a nitric acid solution. The dissolved ashes were transferred to a $25 \mathrm{~mL}$ flask, and rinsed with a small amount of HPLC water and filled to the line. After the sample was mixed thoroughly, it was filtered on Whatman No. 42 filter paper. The mineral content of the sample was determined using atomic absorption with flame (Perkin-Elmer 3300 atomic absorption spectrometer, Uberlingen, Germany) at $422.7 \mathrm{~nm}$ for calcium, $766.5 \mathrm{~nm}$ for potassium, $589.0 \mathrm{~nm}$ for sodium, and $285.2 \mathrm{~nm}$ for magnesium.

\subsubsection{Soluble $\mathrm{Ca}, \mathrm{K}, \mathrm{Na}, \mathrm{Mg}$ :}

Approximately $150 \mathrm{mg}$ of freeze-dried micellar pellet was reconstituted overnight at $4^{\circ} \mathrm{C}$ in $10 \mathrm{~mL}$ of HPLC water. The following morning, the sample was transferred to a $50 \mathrm{~mL}$ volumetric flask, and the beaker was rinsed with a few milliliters of HPLC water. $25 \mathrm{~mL}$ of $24 \%$ TCA was added to the flask and was filled to the line with HPLC water. After mixing, the sample was filtered and Whatman No. 40 filter paper. The mineral content of the sample was determined using atomic absorption with flame (Perkin-Elmer 3300 atomic absorption spectrometer, Uberlingen, Germany) at $422.7 \mathrm{~nm}$ for calcium, 766.5 $\mathrm{nm}$ for potassium, $589.0 \mathrm{~nm}$ for sodium, and $285.2 \mathrm{~nm}$ for magnesium. 


\subsection{Statistical analysis}

All experiments were performed on four different lots of whole fresh milk (unpasteurized) and fresh cream (unpasteurized), so each value represents the mean of four measurements. Statistical analysis was carried out using SAS software (SAS Institute Inc., Cary, NC, USA). Mean comparisons were performed using a Tukey test. Results were considered significantly different when $\mathrm{P}<0.05$. 


\section{RESULTS}

\subsection{Compositional analysis and mass balance of milk components}

The lipid composition for raw cream, raw skim milk, and raw buttermilk was found to be $43.0 \pm 2.7 \%, 0.14 \pm 0.01 \%$, and $3.28 \pm 0.1 \%$, respectively. Total solids measurements were found to be $48.43 \pm 2.3 \%, 9.15 \pm 0.4 \%$, and $12.12 \pm 0.4 \%$, respectively for raw cream, raw skim milk, and raw buttermilk. The evolution of the protein content from fresh raw cream to buttermilk micellar pellet is presented in Figure 4.1.

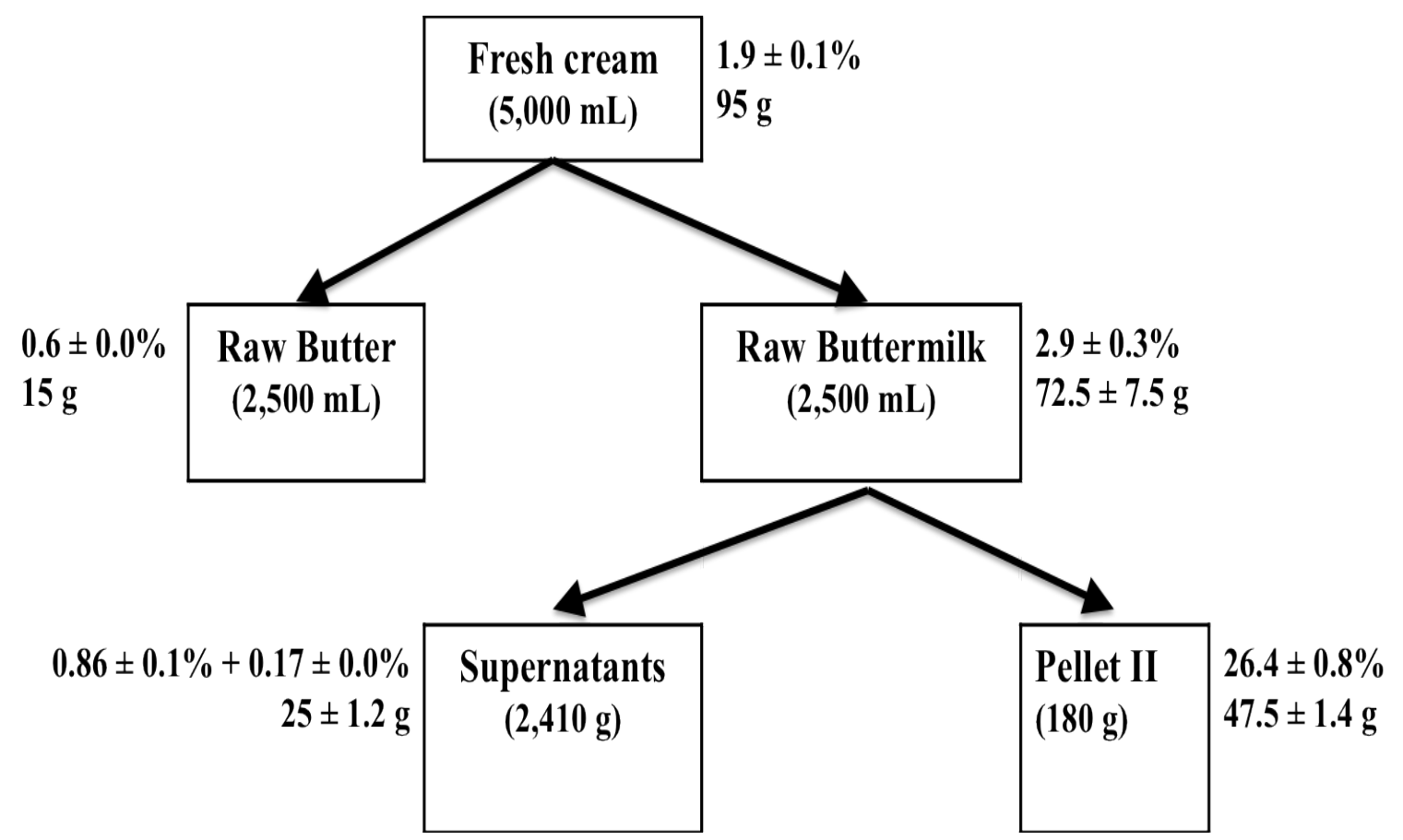

Figure 4.1: Summary of the evolution of the protein content (in \%) and protein mass (in g) during the isolation of the casein micelle of buttermilk. 
Results showed that $76.3 \%$ of the protein from fresh cream to raw buttermilk was recovered after churning. The moisture content of the micellar pellet of the buttermilk was $69.9 \pm 1.1 \%$ and the protein content was $22.4 \pm 0.98 \%$. The protein content in the pellets represents $74.2 \% \pm 3.0 \%, 82.4 \pm 2.8 \%$, and $78.3 \% \pm 1.4 \%$ of the total solids, for raw cream, skim milk, and buttermilk, respectively. Dalgleish and Corredig reported, "casein is the major protein component of bovine milk, comprising approximately $80 \%$ of the total milk protein", which follows the trend seen in the above results (Dalgleish and Corredig, 2012). The protein content of micellar pellets from raw cream and skim milk after ultracentrifugation was found to be $22.2 \pm 1.1 \%$ and $23.4 \pm 2.1 \%$, respectively.

\subsection{One-Dimensional Gel Electrophoresis}

One-dimensional SDS-PAGE gels were run in order to confirm that the isolation of the casein micelles from ultracentrifugation was efficient (Figure 4.2). 


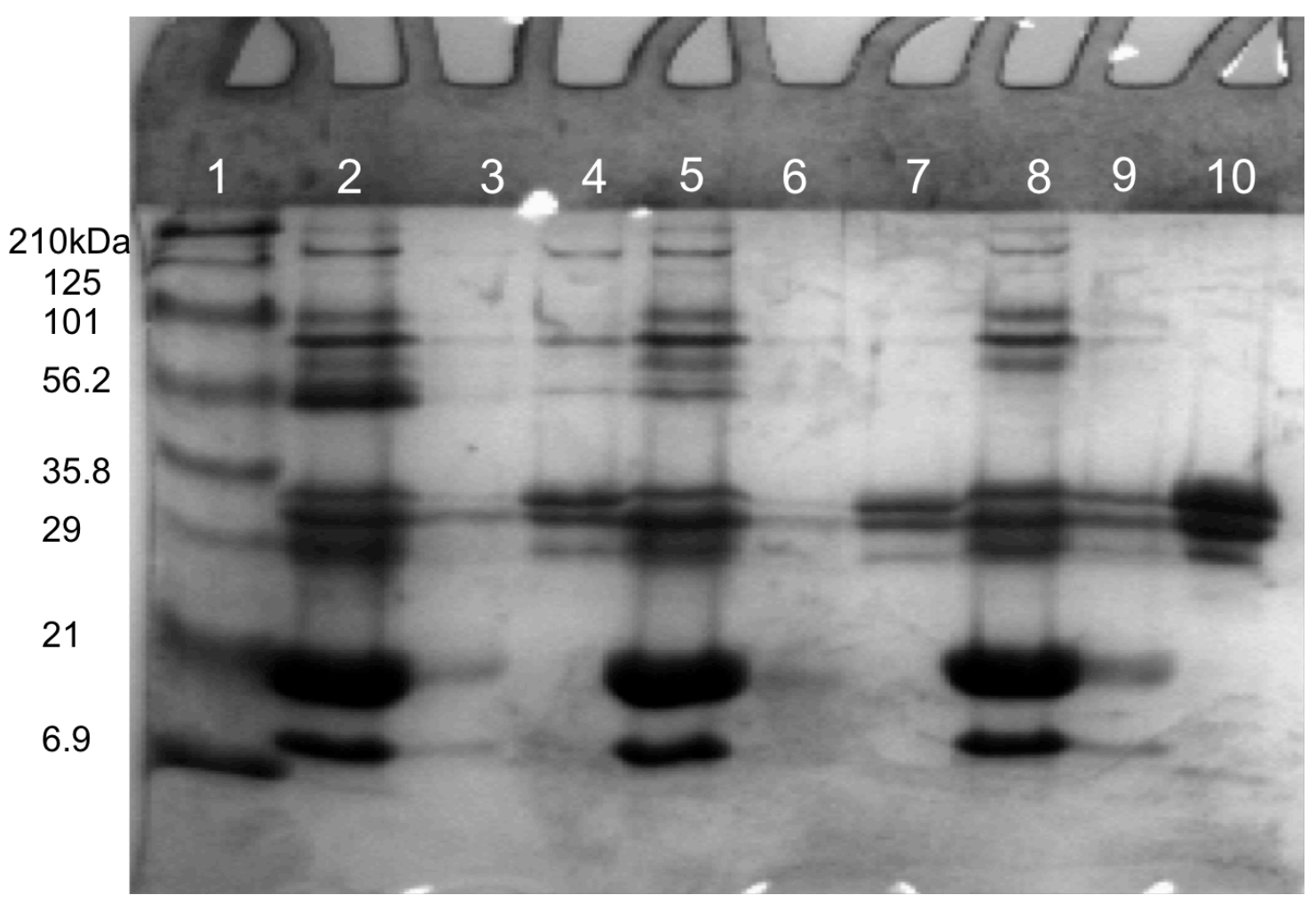

Figure 4.2:One-dimensional gel of casein micelles from the ultracentifugation of raw cream, skim milk, and buttermilk. Key: 1) Broad range molecular weight ladder, 2) buttermilk supernatant 1(diluted 4:1), 3) buttermilk supernatant 2 (diluted 4:1), 4) buttermilk pellet $(4.9 \mathrm{mg} / \mathrm{mL}), 5)$ skim supernatant 1 (diluted 4:1), 6) skim supernatant 2 (diluted 4:1), 7) skim pellet $(4.9 \mathrm{mg} / \mathrm{mL}), 8)$ cream supernatant 1 (diluted 4:1), 9) cream supernatant 2 (diluted 4:1), 10) cream pellet $(4.9 \mathrm{mg} / \mathrm{mL}$ )

When looking at the lane 2, it can be seen that the first supernatant contains a wide range of proteins isolated from raw buttermilk, including some of the MFGM proteins, casein proteins $\left(\alpha_{\mathrm{S} 1}, \alpha_{\mathrm{S} 2}, \beta, \chi\right)$, and whey proteins ( $\alpha$-lactalbumin and $\beta$-lactoglobulin). The following lane (3), supernatant 2 from buttermilk, contains little to no information, showing that a few remaining casein proteins and whey proteins were removed during the second ultracentrifugation (in the presence of the buffer). Finally, the micellar pellet isolated from raw buttermilk (lane 4) contains mostly casein proteins and some residual 
MFGM proteins. This trend can be observed for both the raw cream and skim milk as well. However, it appears that native form of MFGM proteins are recovered in the micellar pellet only for buttermilk, while not in the case of skim milk. Several MFGM proteins can be found in the casein micelle, as seen in Figure 4.3.

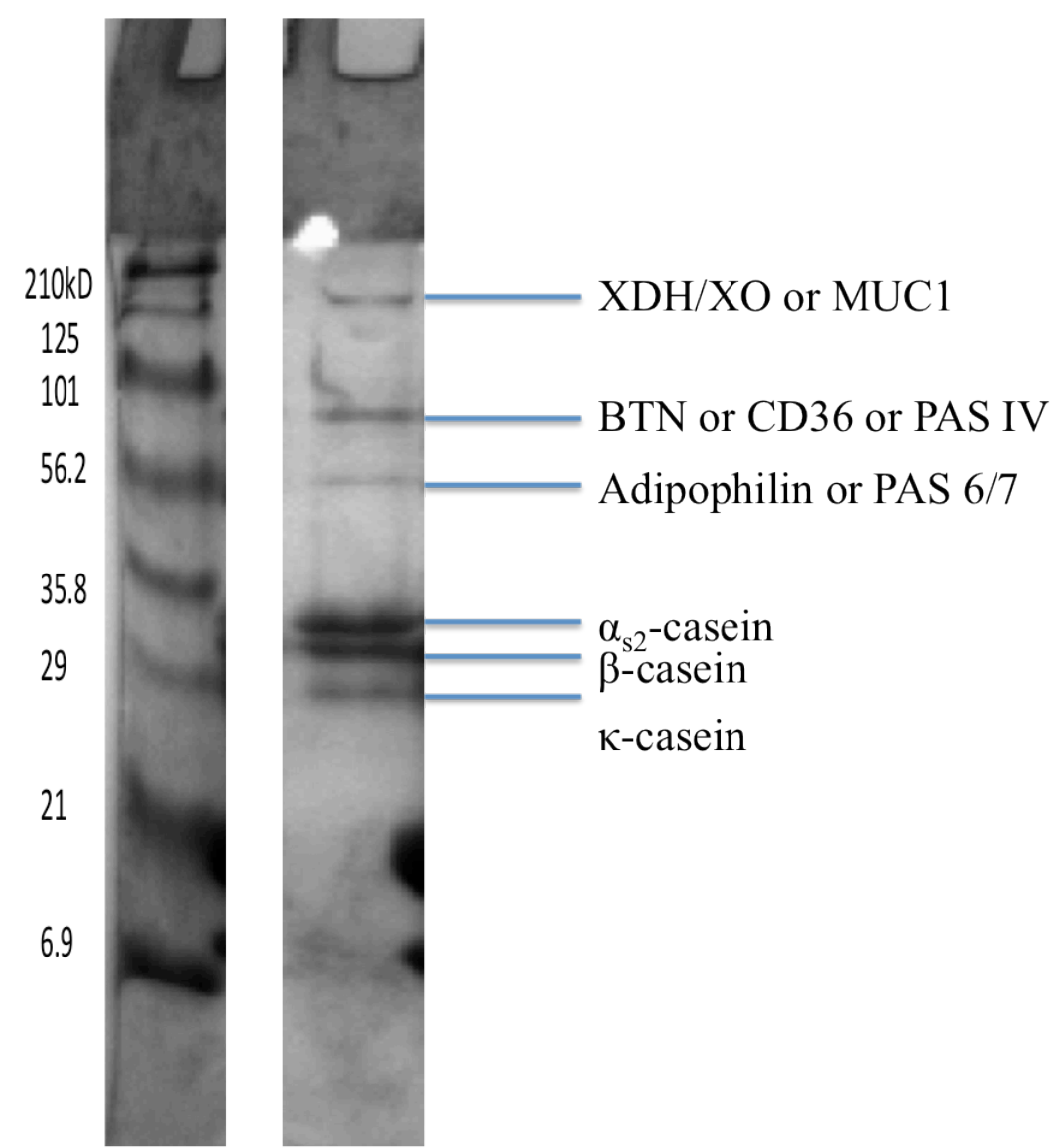

Figure 4.3: Identification of the proteins from the micellar pellet of buttermilk $(4.9 \mathrm{mg} / \mathrm{mL})$ in accordance to their molecular weight.

The following MFGM proteins may be present in the buttermilk micellar pellet according to their molecular weight: xanthine dehydrogenase/oxidase (XDH/XO: $150 \mathrm{kDa})$ or mucine 1 (MUC1: 160-200 kDa), butyrophiline (BTN: $67 \mathrm{kDa}$ ) or cluster of 
differentiation or periodic acid Schiff IV (CD36 or PAS IV: 76-78 kDa) or periodic acid Schiff III (PAS III: 95-100 kDa), and periodic acid Schiff 6/7 (PAS 6/7: 48-54 kDa) or adipophilin (ADPH; $52 \mathrm{kDa}$ ) (Mather, 2000).

\subsection{Particle size distribution and $\zeta$-potential}

The particle size distributions and the $\zeta$-potentials of the casein micelles from cream to buttermilk are presented in Figures 4.4 and 4.5, respectively.

Statistical analysis of the particle size distribution data showed that the average diameter of raw cream was significantly $(P=0.020)$ different from skim milk. There was a significant difference in diameter size between cream $(185.53 \pm 13.94 \mathrm{~nm})$ and skim milk $(138.68 \pm 20.25 \mathrm{~nm})$, but not between cream and buttermilk $(165.80 \pm 20.87 \mathrm{~nm})$ or skim milk and buttermilk.

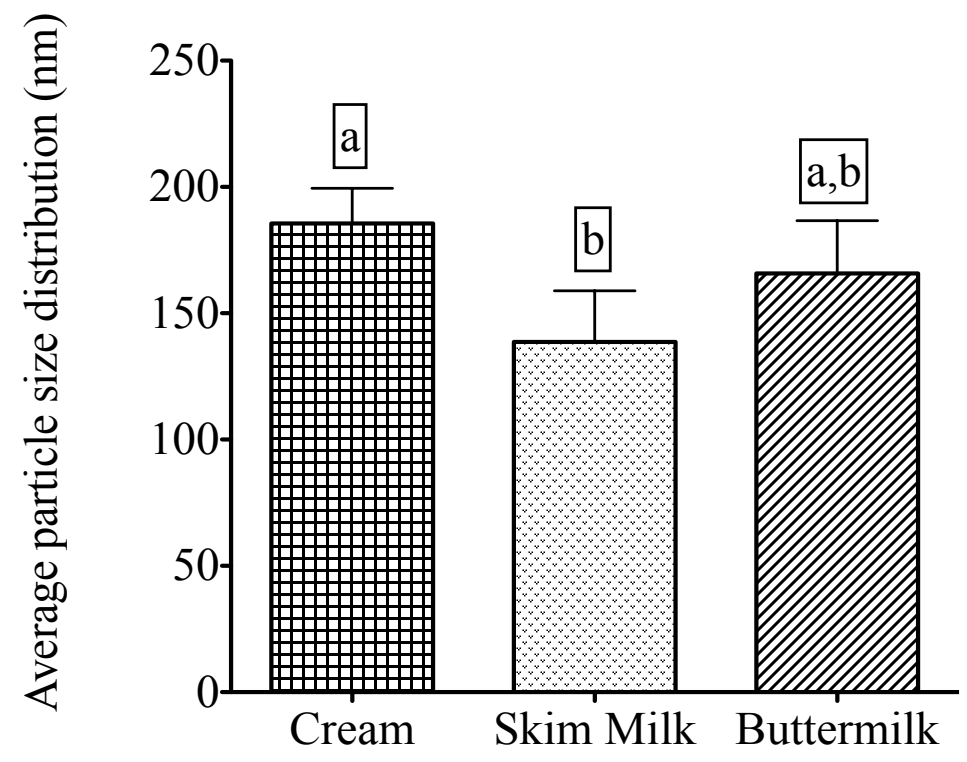

Figure 4.4: Average particle size distribution from raw cream, skim milk, and buttermilk micellar pellets. Means with a different letter are statistically different from each other. 
Statistical analysis of the $\zeta$-potentials data showed that there were no significant differences $(P=0.1377)$ between the samples. $\zeta$-potentials of the casein micelles were $-22.81 \pm 3.59 \mathrm{mV},-18.96 \pm 1.45 \mathrm{mV}$, and $-20.08 \pm 1.29 \mathrm{mV}$, respectively for cream, skim milk, buttermilk. Fox et al report that the average $\xi$-potential of the casein micelle is -20 $\mathrm{mV}$.

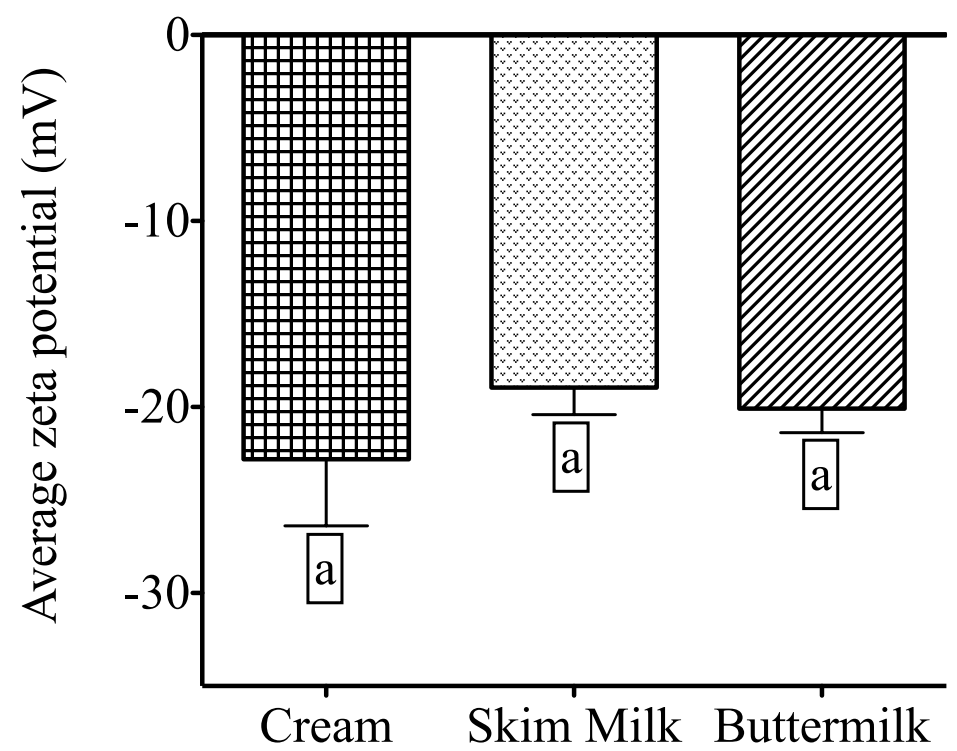

Figure 4.5: Average zeta potential of particles from raw cream, skim milk, and buttermilk micellar pellets. Means with a different letter are statistically different from each other.

\subsection{Two-Dimensional Gel Electrophoresis}

Two-dimensional gels were run to observe the protein profiles of micellar pellets obtained from raw cream, skim milk, and buttermilk as shown in Figure 4.6 to 4.9. 


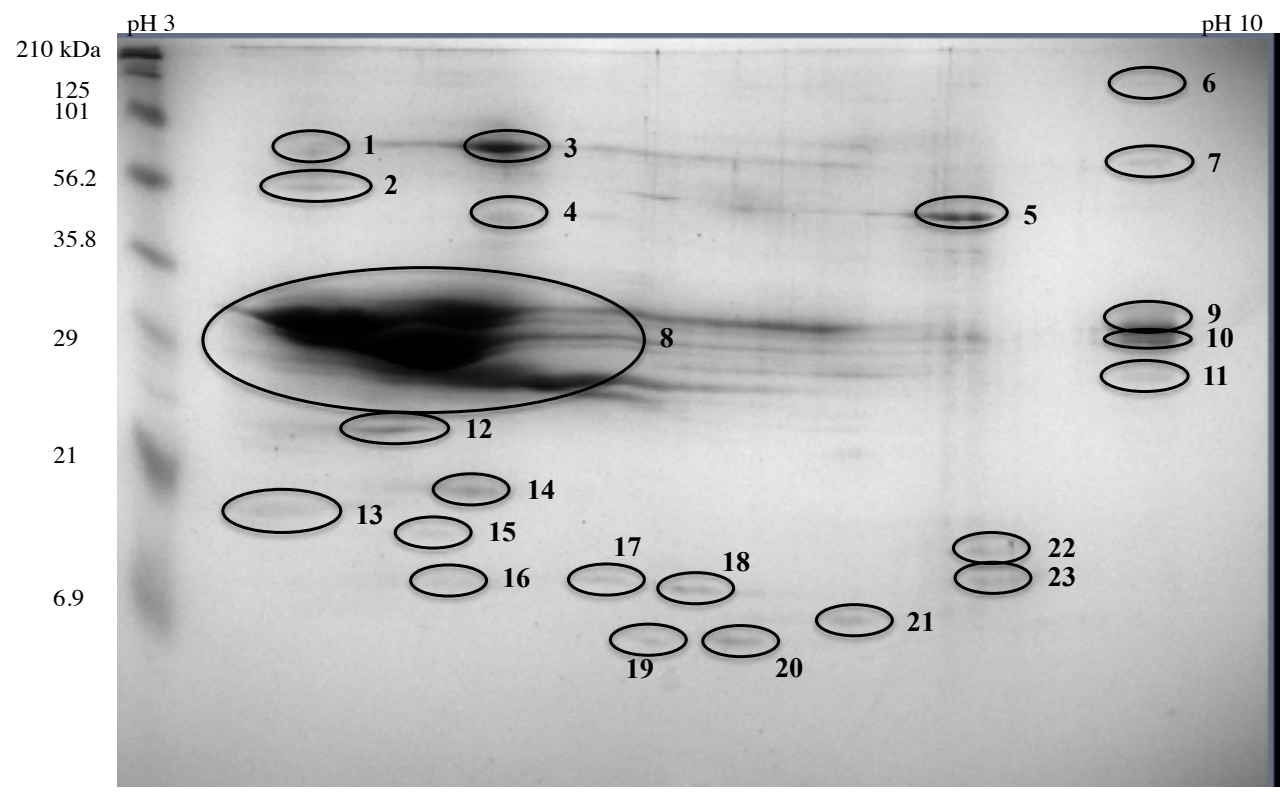

Figure 4.6: 2D-PAGE gel separation of proteins from micellar pellets isolated from raw cream. The gel was loaded with approximately $250 \mu \mathrm{g}$ of proteins and was stained with GelCode Blue Stain. The numbers associated with some spots refer to protein numbers in Table 4.1.

Table 4.1: Proteins identified in the micellar pellet isolated from raw cream. Identification was realized according to Fong et al. (2007) (ID $)$, Bédard $\mathrm{S}^{\mathrm{T}}$-Amand (2009) $\left(\mathrm{ID}_{2}\right)$ or molecular weight (MW)/isoelectric point (pI).

\begin{tabular}{|c|c|c|c|c|c|}
\hline Spot ID & ID $_{1}$ & $\mathrm{ID}_{2}$ & Possible match & MW (kDa) & pI \\
\hline $1-2$ & BTN or MUC1 & BTN & & 59 or 82 & 5.3 or 5.1 \\
\hline 3 & BTN & BTN or BSA & & 59 or 71 & 5.3 or 5.8 \\
\hline 4 & Actin & $\beta$-actin & & 41 & 5.3 \\
\hline 5 & PAS 6/7 & & & 40.8 & 8.2 \\
\hline 6 & & & $\mathrm{XDH} / \mathrm{XO}$ & & \\
\hline 7 & & Lactoperoxidase & & 80.6 & 8.8 \\
\hline 8 & $\begin{array}{l}\text { Caseins }\left(\alpha_{\mathrm{S} 1},\right. \\
\left.\alpha_{\mathrm{S} 2}, \beta, x\right)\end{array}$ & & & 24 to 25 & 4.9 to 5.9 \\
\hline $9-11$ & $\alpha_{\mathrm{S} 2}$ casein & & & 24.5 & 8.54 \\
\hline 12 & PP3 & & & 17.1 & 6.3 \\
\hline 13 & & $\beta$-Lactoglobulin & & 18.3 & 4.9 \\
\hline 14 & $\beta$-Lactoglobulin & $\beta$-Lactoglobulin & & 18.3 & 4.9 \\
\hline 15 & & & $\beta-\mathrm{LG}$ or $\alpha-\mathrm{LA}$ & & \\
\hline 16 & $\alpha-\mathrm{LA}$ & $\alpha-\mathrm{LA}$ & & 14.2 & 4.5 \\
\hline 17 & FABP & & & 14.6 & 6.3 \\
\hline 18 & FABP & FABP & & 14.6 & 6.3 \\
\hline $19-20$ & & & unknown & & \\
\hline $21-23$ & & & $\mathrm{PP}$ & & \\
\hline
\end{tabular}




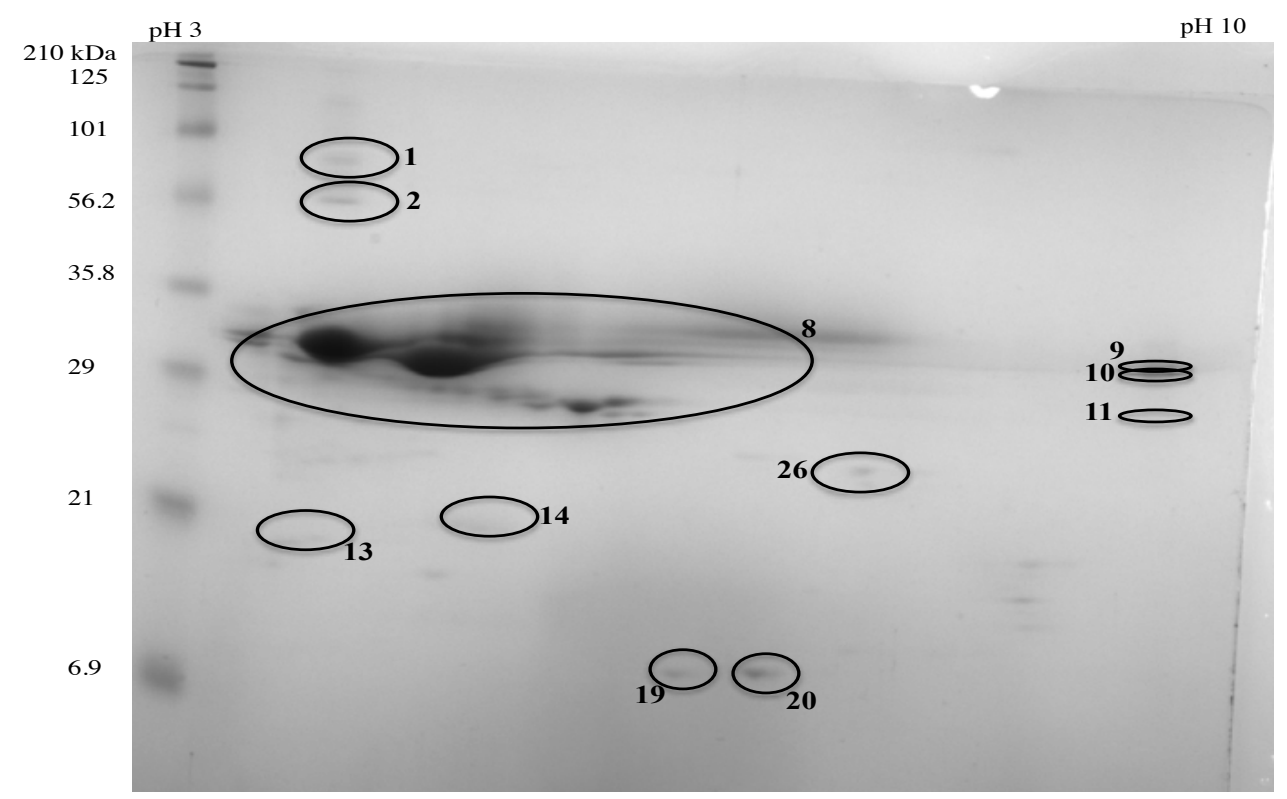

Figure 4.7: 2D-PAGE gel separation of proteins from micellar pellets isolated from raw skim milk. The gel was loaded with approximately $250 \mu \mathrm{g}$ of proteins and was stained with GelCode Blue Stain.

The numbers associated with some spots refer to protein numbers in Table 4.2.

Table 4.2: Proteins identified in the micellar pellet isolated from raw skim milk. Identification was realized according to Fong et al. (2007) $\left(\mathrm{ID}_{1}\right)$, Bédard $\mathrm{S}^{\mathrm{T}}$-Amand (2009) $\left(\mathrm{ID}_{2}\right)$ or molecular weight $(\mathrm{MW}) /$ isoelectric point $(\mathbf{p I})$.

\begin{tabular}{|c|c|c|c|c|c|}
\hline Spot ID & ID $_{1}$ & $\mathrm{ID}_{2}$ & $\begin{array}{l}\text { Possible } \\
\text { match }\end{array}$ & MW (kDa) & pI \\
\hline $1-2$ & BTN or MUC1 & BTN & & 59 or 82 & $\begin{array}{l}5.3 \text { or } \\
5.1\end{array}$ \\
\hline 8 & $\begin{array}{l}\text { Caseins }\left(\alpha_{\mathrm{S} 1}, \alpha_{\mathrm{S} 2},\right. \\
\beta, \varkappa)\end{array}$ & & & 24 to 25 & $\begin{array}{l}4.9 \text { to } \\
5.9\end{array}$ \\
\hline $9-11$ & $\alpha_{\mathrm{S} 2}$ casein & & & 24.5 & 8.54 \\
\hline 13 & & $\beta$-Lactoglobulin & & 18.3 & 4.9 \\
\hline 14 & $\beta$-Lactoglobulin & $\beta$-Lactoglobulin & & 18.3 & 4.9 \\
\hline $19-20$ & & & unknown & & \\
\hline 26 & & & $x$ casein & & \\
\hline
\end{tabular}




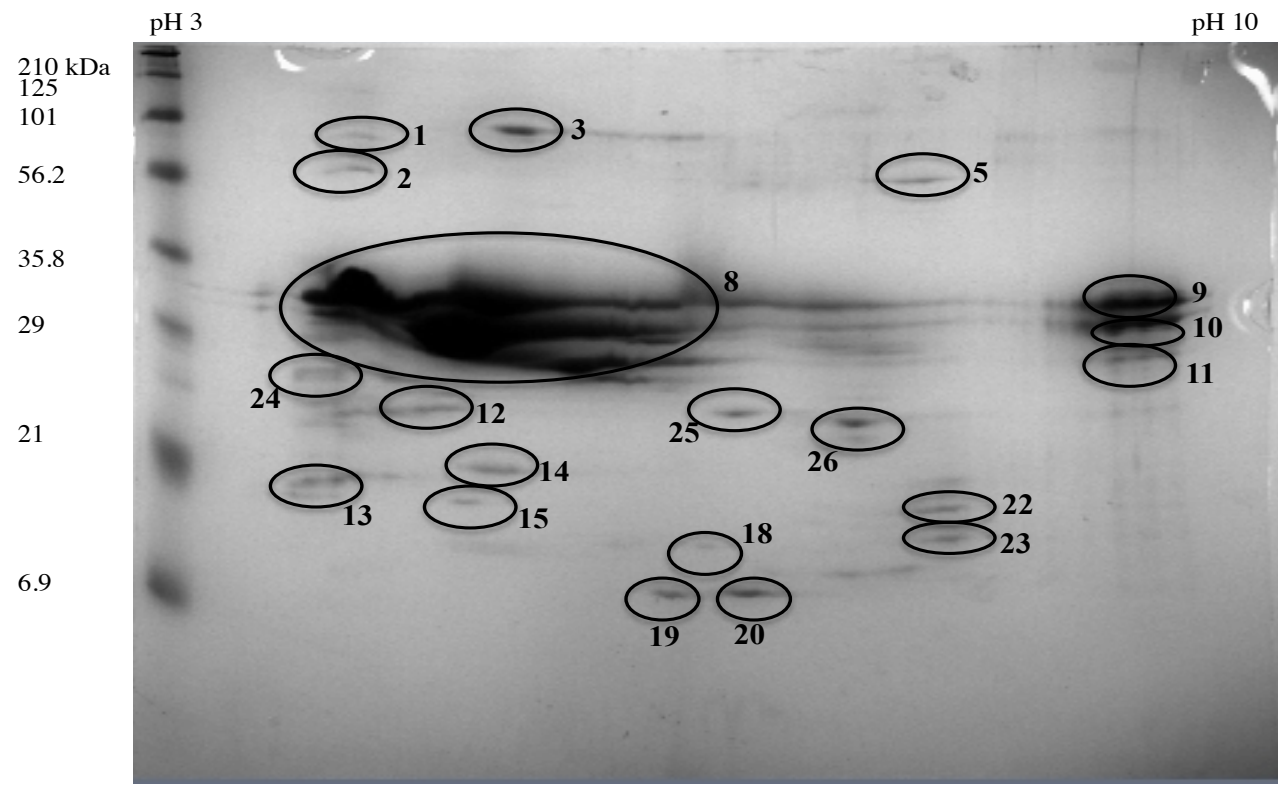

Figure 4.8: 2D-PAGE gel separation of proteins from micellar pellets isolated from raw buttermilk. The gel was loaded with approximately $250 \mu \mathrm{g}$ of proteins and was stained with GelCode Blue Stain.

The numbers associated with some spots refer to protein numbers in Table 4.3.

Table 4.3: Proteins identified in the micellar pellet isolated from raw buttermilk. Identification was realized according to Fong et al. (2007) $\left(\mathrm{ID}_{1}\right)$, Bédard $\mathrm{S}^{\mathrm{T}}$-Amand (2009) $\left(\mathrm{ID}_{2}\right)$ or molecular weight (MW)/isoelectric point (pI).

\begin{tabular}{|c|c|c|c|c|c|}
\hline Spot ID & $\mathrm{ID}_{1}$ & $\mathrm{ID}_{2}$ & Possible match & MW (kDa) & pI \\
\hline $1-2$ & BTN or MUC1 & BTN & & 59 or 82 & 5.3 or 5.1 \\
\hline 3 & BTN & BTN or BSA & & 59 or 71 & 5.3 or 5.8 \\
\hline 4 & Actin & $\beta$-actin & & 41 & 5.3 \\
\hline 5 & PAS 6/7 & & & 40.8 & 8.2 \\
\hline 8 & $\begin{array}{l}\text { Caseins }\left(\alpha_{\mathrm{S} 1},\right. \\
\left.\alpha_{\mathrm{S} 2}, \beta, x\right)\end{array}$ & & & 24 to 25 & 4.9 to 5.9 \\
\hline $9-11$ & $\alpha_{\mathrm{S} 2}$ casein & & & 24.5 & 8.54 \\
\hline 12 & PP3 & & & 17.1 & 6.3 \\
\hline 13 & & $\beta$-Lactoglobulin & & 18.3 & 4.9 \\
\hline 14 & $\beta$-Lactoglobulin & $\beta$-Lactoglobulin & & 18.3 & 4.9 \\
\hline 15 & & & $\beta$-LG or $\alpha-\mathrm{LA}$ & & \\
\hline 18 & FABP & FABP & & 14.6 & 6.3 \\
\hline $19-20$ & & & unknown & & \\
\hline $22-23$ & & & $\mathrm{PP}$ & & \\
\hline 24 & $\alpha_{\mathrm{S} 2}$ casein & BTN sub1 & & & \\
\hline $25-26$ & & & $x$ casein & & \\
\hline
\end{tabular}


The three images above show 2-D PAGE gels of casein micelles isolated from fresh cream, skim milk, and buttermilk. Spots found on the gels have been circled and identified by a corresponding number. Tables 4.1-3 above contain a list of the spots found on the 2-dimensional gel as well as a possible identification of the spot by visual comparison of the molecular weight and pI with two similar studies (Bédard $\mathrm{S}^{\mathrm{T}}$-Amand, 2009; Fong et al., 2007). It can be seen from the three images that there appears to be a similarity between the protein compositions of the three micellar pellets, with the exception of a few spots. When looking at the 2-D gel of casein micelles from fresh cream, it can be seen that there were 24 spots identified, containing casein proteins, MFGM proteins, and a few minor proteins. The results seen from fresh cream are similar to that of buttermilk. However, when looking at skim milk, it can be observed that a majority of the potential MFGM proteins in the upper region $(\sim 80-100 \mathrm{Da})$ of the gel are no longer present, as well as many of the spots located in the low molecular weight $(\sim<$ $21 \mathrm{Da}$ ) and high pI ( 5 to 10) region of the gel. These spots may include proteose peptone proteins as well as residual whey proteins.

There appears to be a greater intensity of some spots found on the 2-dimensional gel from the micellar pellet of buttermilk, especially spots 9,10 , and 11 . These three spots may be $\alpha_{\mathrm{S} 2}$ casein, according to Fong et al. (2008), which may indicate that this protein is more abundant in the buttermilk sample. This same phenomena occurs for spot 8 , which includes the casein proteins $\left(\alpha_{\mathrm{S} 1}, \alpha_{\mathrm{S} 2}, \beta, x\right)$. The spot intensity differences for the casein proteins may verify that there is an unequal distribution of the various proteins between 
the three samples. For example, the two-dimensional gel for the micellar pellet of raw skim milk shows the lesser intensity of the three samples.

Sample preparation involved an extraction with chloroform and methanol, and the dissolution of proteins into aqueous solution. Therefore, some intrinsic proteins may have been lost due to their precipitation during the extraction step or their difficulty to get into solution prior to the isoelectric focusing. Despite these drawbacks, the method was found to be appropriate for this kind of material; 2-D gels obtained (above, figure 4.6 to 4.8) were mostly free from streaking from residual lipids or salts. 


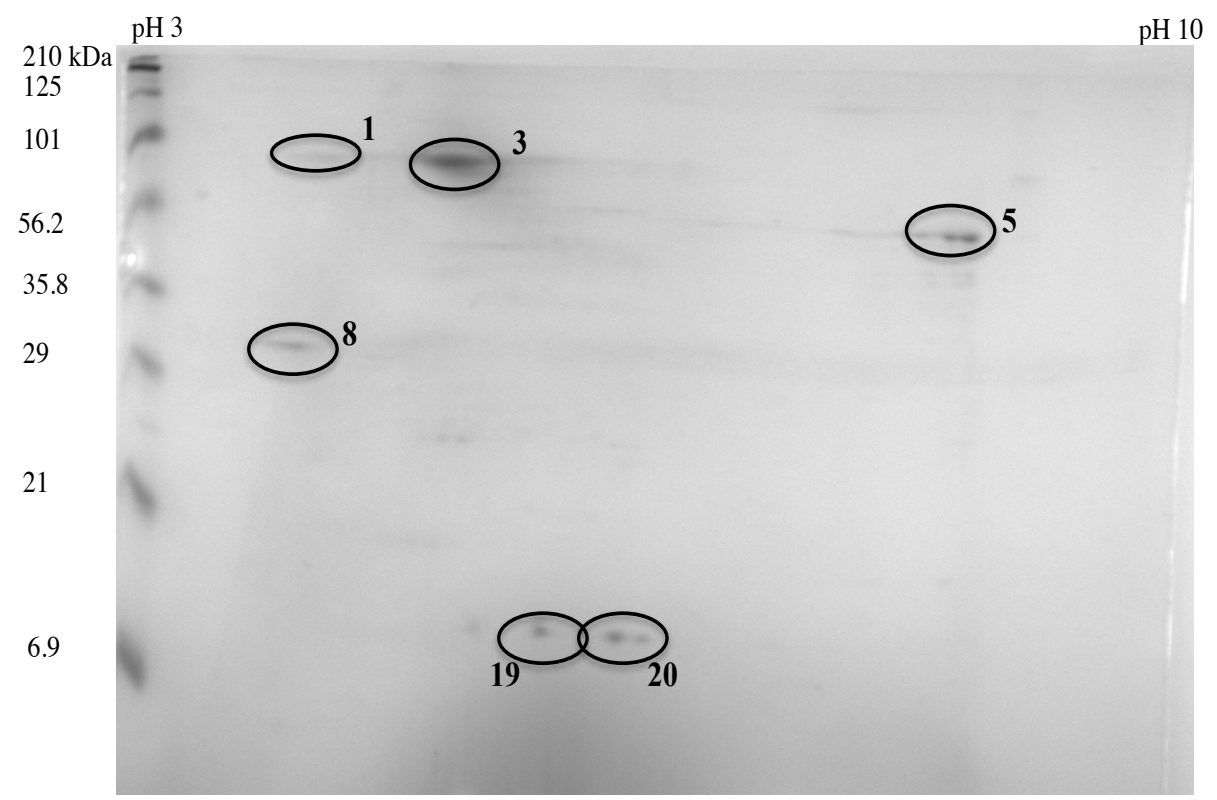

Figure 4.9: 2D-PAGE gel separation of proteins from milk-fat-globule membrane isolated from raw buttermilk. The gel was loaded with approximately $250 \mu \mathrm{g}$ of proteins and was stained with GelCode Blue Stain. The numbers associated with some spots refer to protein numbers in Table 4.4.

Table 4.4: Proteins identified in the milk-fat globule membrane sample isolated from raw buttermilk. Identification was realized according to Fong et al. (2007) (ID $)$, Bédard $S^{T}$-Amand (2009) (ID $)$ or molecular weight (MW)/isoelectric point (pI).

\begin{tabular}{llllll}
\hline Spot ID & ID $_{\mathbf{1}}$ & ID $_{\mathbf{2}}$ & Possible match & MW (kDa) & pI \\
\hline 1 & BTN or MUC1 & BTN & & 59 or 82 & 5.3 or 5.1 \\
3 & BTN & BTN or BSA & & 59 or 71 & 5.3 or 5.8 \\
5 & PAS 6/7 & & 40.8 & 8.2 \\
8 & Caseins $\left(\alpha_{\mathrm{S} 1}\right.$, & & 24 to 25 & 4.9 to 5.9 \\
& $\left.\alpha_{\mathrm{S} 2}, \beta, x\right)$ & & & \\
$19-20$ & & & unknown & & \\
\hline
\end{tabular}

MFGM proteins were isolated from the buttermilk micellar pellets in order better identify their presence after churning with two-dimensional gel electrophoresis. When looking at Figure 4.9 , it can be seen that mostly all casein proteins have been removed successfully (spot 8), with minimal residual protein left. Also, it can be observed in the upper region of the gel (i.e spots 1 and 3) that there remain MFGM proteins that were previously seen 
in figures 4.6 to 4.8, such as BTN or BSA. In the lower region of the gel, spots 19 and 20 are recognized, which were previously unidentified in the 2-dimensional gels above.

\subsection{Salt content of micellar pellets}

The mineral content (total and soluble) of the casein micelles from cream to buttermilk is presented in Tables 4.5 and 4.6, respectively.

Table 4.5: Total mineral content (means \pm SD) found in raw cream, skim milk, and buttermilk; $n=4$.

$$
\mathrm{g} / 100 \mathrm{~g} \text { of freeze-dried micellar pellet }
$$

\begin{tabular}{lcccc}
\hline & K & Ca & Mg & Na \\
\cline { 2 - 5 } Cream & $0.065 \pm 0.02$ & $0.937 \pm 0.06$ & $0.036 \pm 0.005$ & $0.130 \pm 0.02$ \\
Skim milk & $0.076 \pm 0.01$ & $1.012 \pm 0.04$ & $0.039 \pm 0.00$ & $0.135 \pm 0.02$ \\
Buttermilk & $0.092 \pm 0.02$ & $0.962 \pm 0.08$ & $0.039 \pm 0.005$ & $0.147 \pm 0.03$ \\
\hline
\end{tabular}

Table 4.6: Soluble mineral content (means \pm SD) found in raw cream, skim milk, and buttermilk; $n=4$.

$\mathrm{g} / 100 \mathrm{~g}$ of freeze-dried micellar pellet

\begin{tabular}{lcccc}
\hline & \multicolumn{1}{c}{ K } & Ca & Mg & Na \\
\cline { 2 - 5 } Cream & $0.256 \pm 0.02$ & $2.527 \pm 0.05^{\mathrm{a}}$ & $0.102 \pm 0.005$ & $0.308 \pm 0.01$ \\
Skim milk & $0.249 \pm 0.03$ & $2.585 \pm 0.05^{\mathrm{a}}$ & $0.105 \pm 0.005$ & $0.282 \pm 0.01$ \\
Buttermilk & $0.236 \pm 0.05$ & $2.359 \pm 0.05^{\mathrm{b}}$ & $0.097 \pm 0.005$ & $0.306 \pm 0.02$ \\
\hline
\end{tabular}

a. Values in same column for each mineral with different superscript differs significantly $(\mathrm{p}<0.05)$ 
Statistical analysis of data showed that soluble calcium of buttermilk micellar pellets was statistically different $(P=0.0001)$ from cream and skim milk. There was a significant difference between the content of soluble calcium in the micellar pellet of buttermilk $(2.359 \pm 0.05 \mathrm{~g} / 100 \mathrm{~g}$ of freeze-dried micellar pellet) and the soluble calcium content in cream and skim milk micellar pellet $(2.527 \pm 0.05$ and $2.585 \pm 0.05 \mathrm{~g} / 100 \mathrm{~g}$ of freezedried micellar pellet, respectively)

\subsection{Phosphorus}

The phosphorus content of the micellar pellets was determined in order to identify possible interactions between casein micelles and phospholipids due to processing. The phosphorus content of the casein micelles from cream to buttermilk is presented in Table 4.7 .

There are two types of phosphorus measured: one in which is involved in the casein micelle structure through the colloidal calcium phosphate bonds (CCP), identified as casein bound phosphorus. The other type observed is involved in the structure of phospholipids, which includes the three sub-categories below: Total inorganic phosphorus; soluble+colloidal, esterified; and soluble+colloidal. Statistical analysis of data showed that the soluble+colloidal phosphorus content of the micellar pellet of buttermilk was almost significantly different from cream and skim milk $(P=0.058)$. There was no significant difference for casein bound phosphorus of the micellar pellets measured $(P>0.05)$. 
Table 4.7: Phosphorus contents (means \pm SD) of raw cream, skim milk, and buttermilk; $n=4$.

$\mathrm{g} / 100 \mathrm{~g}$ of freeze-dried micellar pellet

\section{Total* $\quad$ Soluble+colloidal $\quad$ Soluble+colloidal $\quad$ Casein bound}

, esterified

\begin{tabular}{lcccc}
\hline Cream & $1.736 \pm 0.03$ & $1.419 \pm 0.23$ & $1.177 \pm 0.01^{\mathrm{a}}$ & $0.286 \pm 0.22$ \\
Skim milk & $1.887 \pm 0.19$ & $1.681 \pm 0.08$ & $1.195 \pm 0.02^{\mathrm{a}}$ & $0.288 \pm 0.09$ \\
Buttermilk & $1.576 \pm 0.12$ & $1.398 \pm 0.01$ & $1.092 \pm 0.04^{\mathrm{b}}$ & $0.246 \pm 0.01$ \\
\hline
\end{tabular}

a. Values in same column for each phosphorus type with different superscript differs significantly (p $<0.05)$

Total* soluble + colloidal, esterified, casein bound 


\section{GENERAL DISCUSSION}

With a composition similar to skim milk, buttermilk has a strong potential of protein recovery usable in the manufacture of food formulation and more specifically, in the cheese industry. Buttermilk represents an appealing source of casein to fortify cheese milk because of its relatively low value and the presence of phospholipids in buttermilk that can help improve the texture of low fat cheeses (Turcot et al., 2001). However, as presented in the literature review, there are some changes that occur to the casein micelles that limit its industrial potential.

The first objective of the study was to find a method to isolate the casein micelle from raw cream, skim milk, and buttermilk, while preserving the native form of the micelle as much as possible. There have been many protocols that have been proposed, and one was chosen in order to fit the needs of the present work. The method used by Corredig and Dalgleish (1996b) was followed because the buffer used allowed to stabilize the micellar material and to observe it in its native state while washing away any uncomplexed whey proteins from the micellar pellet. The one-dimensional gels showed that a majority of the caseins were recovered in the micellar pellet. According to (Dalgleish and Corredig, 2012), 80\% of the casein proteins are present in the micellar form. This fact could explain the loss of casein proteins during the first ultracentrifugation of the isolation protocol. The choice of buffer was maintained throughout the experiment due to successful isolation. In consequence, the micellar pellets could be used to understand the effect of the butter-making process on the casein micelle physiochemical properties. 
Physical properties of the casein micelle were measured in order to determine the impact of skimming and churning on the size distribution and zeta potential. The particles in the buttermilk or cream micellar pellets were composed of two different species with two different size ranges (peaks). Most of the particles were present in the peak corresponding to the smallest average diameters (140 to $200 \mathrm{~nm}$ ) and were consistent to the average size of casein micelles (Fox and McSweeney, 2003). Small proportions $(<1 \%)$ of large particles $(\geq 4,000 \mathrm{~nm})$ formed a second peak in both cream and buttermilk samples, which corresponded to residual fat from centrifugation of cream and buttermilk (Fox and McSweeney, 2003).

Overall, it can be seen that skimming and churning did not modify the size of the particles and the zeta potential of the casein micelles. It is of interest to note that the zeta potential did slightly increase for the buttermilk sample when compared to cream. The most probable reason why the zeta potential increased is due a contamination on the surface of the casein micelle though the attachment of other proteins. The modification of the physical properties of the casein micelles after skimming or churning could be due to changes in the protein or salt distribution.

Calcium content was measured in order to determine if the effect of physical properties of the micelle was due to changes in the salt distribution. Results showed a significantly lower amount of soluble Calcium in the micellar pellet of buttermilk when compared to cream or skim milk samples. Calcium is important in the overall structure of the 
colloidal calcium phosphate of the casein micelle, which then allows it to play an interesting role in the rheological properties of milk. These results are comparable to the work done by Bédard $S^{\mathrm{T}}$-Amand (2009), in which it was observed that the soluble salt content of buttermilk is decreased after HTST pasteurization, indicating the poor coagulation properties. O'Connel and Fox (2000) have reported that the lower amount of calcium in buttermilk was relatively responsible for the longer rennet coagulation time, as compared to skim milk. However, because soluble Calcium was found to be the only significant salt constituent in buttermilk, it is known that the size difference found was not due to the structural bonds of the micelle.

Similarly, the phosphorus content of the micellar pellet was measured to observe if the phospholipid content was changed during the skimming or churning process. One of the hypotheses in the current work was that churning of cream promotes an interaction between the micelle and phospholipids. For soluble+colloidal phosphorus, it is likely that the colloidal phosphorus is associated with the casein bound phosphorus, and the soluble phosphorus is that which is able to be in solution. Because there is no significant difference for casein bound phosphorus, it is likely that there is not a difference in the phospholipid content of the micellar pellet obtained from buttermilk versus cream or skim milk. It appears from the results that there are less phospholipids found in the micellar pellet of buttermilk, but in the same proportion bound as found in the cream before churning. The interactions that may have occurred can be better known by observing the composition of the micellar pellet with two-dimensional gel electrophoresis. 
Two-dimensional gels allowed for a better identification of the protein composition in the micellar pellet after mechanical treatment was applied. It was found that there were some residual MFGM proteins present in the buttermilk sample in both the one and twodimensional gels. This could be explained by the fact that during the churning process of cream, the fat globules are broken down and MFGM proteins are released.

Some minor proteins were present in the 2-dimensional gel of the buttermilk sample, which may indicate possible interactions that occurred after the skimming and before the end of the churning process. These proteins were not identified with certainty, but it is suspected that they may be $x$-casein and/or FABP due to their molecular weight and isoelectric point. It has been hypothesized that during the churning process of cream, the inner membrane of the fat globules are exposed to milk serum, which may induce possible interactions or dislocation of the MFGM (Morin et al., 2007). It is known from literature that there are hydrophobic interactions that occur between the casein micelle and MFGM proteins (Morin, 2006). Interactions with these minor proteins appeared to be strong, as they were able to withstand the ultracentrifugation and washing steps of the isolation of the micellar pellet. The experiments done by Bédard $S^{\mathrm{T}}$-Amand (2009) yielded stronger significance because the changes that occurred were during the pasteurization process. However, it was found in the current results that mechanical forces also impact the constituents of the micelle. The most noted change is the appearance of proteins in the micellar pellet of buttermilk. It is more likely that churning released some Butyrophilin (spot 24), proteose peptone (spot 22-23), and even some $x$ - 
casein because they were not present in the micellar pellet of cream. On the other hand, Izmiroglu (2010) concluded that the MFGM proteins (specially BTN) were more abundant in the micellar pellet of buttermilk after a heat treatment. Unfortunately, the results from Izmiroglu do not permit to distinguish if this phenomenon is due to the heating alone or the combination of heating and churning.

Moreover, caseins were present in the MFGM isolate material suggesting strong interactions between both. Bédard $S^{T}$-Amand (2009) showed that interactions between MFGM proteins and whey proteins or caseins became more important as a function of the heating temperature.

Overall, results of the current work showed that the modifications of the casein micelle are not solely attributed to the pasteurization of cream or skim milk, but also to the physical treatment applied during the processing steps of cheese or butter (such as churning or skimming). The remaining challenge is to find which form of treatment, either heat or physical, attributes to the most important changes of the micelle. With this information, more will be known about ways in which to better use the casein micelle from buttermilk. 


\section{GENERAL CONCLUSIONS}

The goal of the work presented in this thesis was to characterize the changes of physical treatment on the composition and physiochemical properties of casein micelles from cream to buttermilk. The general hypothesis of this thesis was that casein micelles separated from buttermilk reveal differences in composition resulting from interactions with MFGM components and minor lipids.

The work carried out allowed us to validate our hypothesis. Skimming and churning modified both the structure and properties of the casein micelle from buttermilk, such as a smaller size and decrease in soluble Calcium. Finally, results showed the presence of possible interactions with between micellar proteins and MFGM components.

To our knowledge, the work presented in this thesis will be the first investigation of the effect of physical treatment on the casein micelle recovered from buttermilk. Many conclusions have been made about the changes occurring due to pasteurization of the milk. It is, however, likely that some of the changes are occurring due to physical treatment as well.

The results presented in this thesis are expected to have an impact in various facets of the dairy industry. A better understanding of the changes that occur to the casein micelle during butter making allow us to learn more about how to improve the potential of buttermilk for food formulation. 
However, it appears to be difficult to minimize the changes that occur, particularly because of the industry-wide standards for pasteurization and churning methods. More can be done on a pilot scale in order to determine if there is a speed or temperature point at which these interactions and physical changes can be reduced. Moreover, further investigating of structural changes with confocal microscopy may provide insight into the way in which physical treatment of milk alters the overall structure of the casein micelle. Investigating changes in rheological properties may also be of interest in the dairy industry because it will lead to a better understanding of the cheese-making properties of buttermilk. 


\section{REFERENCES}

Allen, R.J.L., (1940). The Estimation of Phosphorus. Biochemical Journal 34(6), 858865.

Anema, S.G., Li, Y., (2003). Association of denatured whey proteins with casein micellesin heated reconstituted skim milk and its effect on casein micelle size. Journal of Dairy Research 70(73-83).

Appel, K.C., Keenan, T.W., Low, P.S., (1982). Differential scanning calorimetry of milk fat globule membranes. Biochimica et Biophysica Acta 690, 243-250.

Barratt, M.D., Austin, J.P., Whitehurst, R.J., (1974). The influence of the alkyl chain length of Lecithins and Lysolecithins on their interaction with $\alpha$ s1-casein. Biochimica et Biophysica Acta 34, 126-135.

Bédard S $\mathrm{S}^{\mathrm{T}}$-Amand, J., (2009). Effet de la pasteurisation haute du babeurre sur sa composition minérale et celle des constituants protéiques des fragments de la membrane du globule gras du lait, Department of Food Science and Nutrition Université Laval, Quebec City, p. 119.

Boudreau, A., St-Amant, L., (1984). Beurre. Sciences et technologie du lait , 213-240. 
Brisson, G., Payken, H.K., Sharoe, J.P., Jiménez-Flores, R., (2010). Characterization of Lactobacillus reuteri interaction with milk fat globule membrane components in dairy products. Journal of Agricultural and Food Chemistry 58(9), 5612-5619.

Britten, M., Pouliot, Y., (2002). Rôles fonctionnels du calcium en industrie laitière, Résumé de cours-séminaire, Agriculture et Agroalimentaire Canada.

Brooks, I.B., Luster, G.A., Easterly, D.B., (1970). A procedure for the rapid determination of the major cations in milk by atomic absorption spectrophotometry. Atomic Absorption Newsletter 9, 93.

Brulé, G., Lenoir, J., Remeuf, F., (1997). La micelle de caséine et la coagulation du lait (3 ed). Tec doc.

Bylung, G., (1995). Dairy processing handbook. Tetra Pak Processing Systems AB.

Cheng, S.G., Koch, U., Brunner, J.R., (1988). Characteristics of putrified cows ' milk Xanthine oxydase and its submolecular characteristics. Journal of Dairy Science 71(4), 901-916.

Corredig, M., Dalgleish, D.G., (1996a). Effect of different heat treatment on the strong binding interactions between whey proteins and milk fat globules in whole milk. Journal of Dairy Research 63, 441-449. 
Corredig, M., Dalgleish, D.G., (1996b). Effect of temperature and pH on the interactions of whey proteins with casein micelles in skim milk. Food Research International 29(1), 49-55.

Corredig, M., Dalgleish, D.G., (1997). Isolates from industrial buttermilk: Emulsifying properties of materials derived from the milk fat globule membrane. Journal of Agricultural and Food Chemistry 45, 4595-4600.

Costa, M.R., Elias-Argote, X.E., Jiménez-Flores, R., Gigante, M.L., (2010). Use of ultrafiltration and supercritical fluid extraction to obtain a whey buttermilk powder enriched in milk fat globule membrane phospholipids. International Dairy Journal 20, 598-602.

Dalgleish, D.G., Corredig, M., (2012). The structure of the casein micelle of milk and its changes during processing. The Annual Review of Food Science and Technology 3, 449467.

Danthine, S., Blecker, C., Paquot, M., Innocente, N., Deroanne, C., (2000). Progress in milk fat globule membrane research: A review. Lait 80, 209-222.

Dapper, C.H., Valivullah, H.M., Keenan, T.W., (1987). Use of polar aprotic-solvents to release membranes from milk lipid globules. Journal of Dairy Science 70(4), 760-765. 
Darling, D.F., Dickson, J., (1979). The determination of the $\zeta$-potential of casein micelles. Journal of Dairy Research 46, 329.

Dewettinck, K., Rombaut, R., Thienpont, N., Le, T.T., Messens, K., Van Camp, J., (2008). Nutritional and technological aspects of milk fat globule membrane material. International Dairy Journal 18, 436-457.

Donato, L., Guyomarc'h, F., (2009). Formation and properties of the whey protein/Kcasein complexes in heated skim milk -A review. Dairy Science and Technology 89, 329.

Donato, L., Guyomarc'h, F., Amiot, S., Dalgleish, D.G., (2007). Formation of whey protein-k-casein complexes in heated milk : Preferential reaction of whey protein with kcasein in the casein micelles. International Dairy Journal 17, 1161-1167.

Dufourcq, J., Faucon, J.F., (1977). Intrinsic fluorescence study of lipid-protein interactions in membrane models. Binding of melittion, an amphipathic peptide, to phospholipid vesicles. Biochimica et Biophysica Acta 467, 1-11.

FAO, (2013). World milk production, http://www.dairyco.org.uk/marketinformation/supply-production/milk-production/world-milk-production/ .UonlJ6WKT88. 
Fong, B.Y., Norris, C.S., MacGibbon, A.K.H., (2007). Protein and lipid composition of bovine milk gat globule membrane. International Dairy Journal 17, 275-288.

Fong, B.Y., Norris, C.S., Palmano, K.P., (2008). Fractionation of bovine whey proteins and characterisation by proteomic tecniques. International Dairy Journal 18(1), 23-46.

Fortunato, D., Giuffrida, M.G., Cavaletto, M., Garoffo, L.P., Dellavalle, G., Napolitano, L., Giunta, C., Fabris, C., Bertino, E., Coscia, A., Conti, A., (2003). Structural proteome of human colostral fat globule membrane proteins. Proteomics 3, 897-905.

Fox, P.F., McSweeney, P.L.H., (2003). Advances in dairy chemistry - Proteins. Kluwer Academic/Plenum Publisher, New York.

Gallier, S., Gordon, K.C., Jiménez-Flores, R., Everett, D.W., (2011). Composition of bovine milk fat globules by confocal Raman microscopy. International Dairy Journal 21(6), 402-412.

Gallier, S., Gragson, D., Cabral, C., Jiménez-Flores, R., Everett, D.W., (2010). Composition and fatty acid distribution of bovine milk phospholipids from processed milk products. Journal of Agricultural and Food Chemistry 58, 10503-10511.

Gaucheron, F., Le Graët, Y., Schuck, P., (2004). Equilibres minéraux et conditions physicochimiques. Edition Tec \& Doc, Lavoisier, Paris, France. 
Gezimati, J., Singh, H., Creamer, L.K., (1996). Heat-induced interactions and gelation of mixtures of bovine $\beta$-lactoglobulin and serum albumin. Journal of Agricultural and Food Chemistry 44, 804-810.

Goff, H.D., Hill, A.R., (1993). Chemistry and physics. VCH Publishers, New York, NY.

Goudedranche, H., Fauquant, J., Maubois, J.L., (2000). Fractionation of globular milk fat by membrane microfiltration. Lait 80(1), 93-98.

Havea, P., Singh, H., Creamer, L.K., (2000). Formation of new protein structures in heated mixtures of BSA and $\alpha$-lactalbumin. Journal of Agricultural and Food Chemistry $48,1548-1556$.

Heid, H.S., Schnölzer, M., Keenan, T.W., (1996). Adipocyte differentiation-related protein is secreted into milk as a constituent of milk lipid globule membrane. Biochemistry Journal 320, 1025-1030.

Holt, C., Horne, D.S., (1996). The hairy casein micelle: evolution of the concept and its implication for dairy technology. Netherlands Milk and Dairy Journal 50, 85-111.

Horne, D.S., (2006). Casein micelle structure: Models and muddles. Current Opinion in Colloid \& Interface Science 11, 148-153. 
Houlihan, A.V., Goddard, P.A., Nottingham, S.M., Kitchen, B.J., Masters, C.J., (1992). Interactions between the bovine milk fat globule membrane and skim milk components on heating whole milk. Journal of Dairy Research 59, 187-195.

Hvarregaard, J., Andersen, M.K., Berglund, L., Rasmussen, J.T., Petersen, T.E., (1996). Characterization of glycoprotein PAS-6/7 from membranes of bovine milk fat globules. European Journal of Biochemistry 240, 628-636.

IDF, (2002). Determination of nitrogen content routine method using combustion according to the Dumas principle. IDF 186 Brussels(Belgium).

IDF, (2008). Skim milk, whey and buttermilk. Determination of fat content - Gravimetric method (Reference method). International Dairy Federation, Brussels, Belgium Standard 22.

Izmiroglu, S., (2010). Effet de la pasteurisation sur les interactions entre les protéines de la membrane de globule de gras laitier et les micelles de caséine du babeurre. Université Laval, Quebec City.

Kanno, C.M., Kim, D.H., (1990). A simple procedure for the ppreparation of bovine-milk fat globule membrane and a comparison of its composition, enzymatic-activities, and 
electrophoretic properties with those prepared by other methods. Agricultural and Biological Chemistry 54, 2845-2854.

Keenan, T.W., Dylewski, D.P., (1995). Intracellular origin of milk lipid globules and the nature of structure of milk fat globule membrane, in: Fox, P.F. (Ed.), Advanced dairy chemistry Lipids, vol. 2. Chapman \& Hall, London.

Keenan, T.W., Mather, I.H., (2006). Intracellular origin of milk fat globules and the nature of the milk fat globule membrane, in: Birkhäuser (Ed.), Advanced Dairy Chemistry: Lipids. P.F.Fox, P.L.H. McSweeney, pp. 137-170.

Laemmli, U.K., (1970). Cleavage of structural proteins during the assembly of the head of bacteriophage T4. Nature 227(5259), 680-685.

Livney, Y.D., Dalgleish, D.G., (2004). Specificity of disulfide bond formation during thermal aggregation in solution of beta-lactoglobulin B and kappa-casein A. Journal of Agricultural and Food Chemistry 52, 5527-5532.

Lopez, C., (2007). The composition, supramolecular organisation and thermal properties of milk fat: a new challenge for the quality of food products. Lait 87, 317-336.

Lopez, C., Briard-Bion, V., Menard, O., Rousseau, F., Pradel, P., Besle, J.M., (2008). Phospholipids, sphingolipid, and fatty acid compositions of the milk fat globule 
membrane are modified by diet. Journal of Agricultural and Food Chemistry 56(13), 5226-5236.

Ma, Y., Barbano, D.M., (2000). Gravity separation of raw bovine milk: Fat globule size distribution and fat content of milk fractions. Journal of Dairy Science 83, 1719-1727.

Malvern Instrument SA, (2009). Zetasizer nano user manual, in: http://malvern.com/en/support/resource-center/user-manuals/MAN0485EN.aspx (Ed.).

Mather, I.H., (2000). A review and proposed nimenclature for major proteins of the milkfat globule membrane. Journal of Dairy Science 83, 203-247.

McMahon, D.J., Brown, R.J., (1984). Composition, structure, and integrity of casein micelles: A review. Journal of Dairy Science 67(3), 499-512.

McPherson, A.V., Kitchen, B.J., (1983). Review of the progress of dairy science: the bovine milk fat globule membrane- its formation and secretion of fat globules and origin of MFGM. Journal of Dairy Research 50, 107-133.

Mistry, V.V., Metzger, L.E., Maubois, J.1., (1996). Use of Ultrafiltered sweet buttermilk in the manufacture of reduced fat cheddar cheese. Journal of Dairy Science 79, 11371145. 
Morin, P., (2006). On the fractionation of buttermilk by microfiltration membranes, Department of Food Science and Nutrition Université Laval, Quebec City, p. 155.

Morin, P., Jiménez-Flores, R., Pouliot, Y., (2007). Effect of processing on the composition and microstructure of butermilk and its milk fat globule membranes. International Dairy Journal 17, 1179-1187.

Mulder, H., Walstra, P., (1974). The milk fat globule emulsion science as applied to milk products and comparable foods. PUDOC, Wageningen, The Netherlands.

Needs, E.C., Capellas, M., Bland, A.P., Manoj, P., Macdougal, D., Paul, G., (2000). Comparison of heat and pressure treatments of skim milk, fortified with whey protein concentrate, for set yogurt preparation: effects on milk proteins and gel structure. Journal of Dairy Research 67, 329-348.

O'Connel, J.E., Fox, P.F., (2000). Heat stability of Buttermilk. Journal of Dairy Science $83,1728-1732$.

O'Mahony, F., (1988). Rural dairy technology - Experiences in Ethiopia, in: Africa, D.T.U.-I.L.C.f. http://www.ilri.org/InfoServ/Webpub/fulldocs/ilca_manual4/Toc.htm - TopOfPage. P.O. Box 5689, Addis Ababa, Ethiopia. 
Ong, R.L., Marchesi, V.T., Prestegard, J.H., (1981). Small unilamellar vesicles containing Glycophorin A. Chemical characterization and proton nuclear magnetic resonance studies. Biochemistry 20(15), 4283-4292.

Pallesen, L.T., Andersen, M.H., Nielsen, R.L., Berglund, L., Petersen, T.E., Rasmussen, L.K., Rasmussen, J.T., (2001). Purification of MUC1 from bovine milk-fat globules and characterization of a corresponding full-length cDNA clone. Journal of Dairy Science 84, 2591-2598.

Patton, S., Keenan, T.W., (1975). Milk-fat globule membrane. Biochemica et Biophysica Acta 415(3), 273-309.

Pierre, A., Brule, G., (1981). Mineral and protein equilibria between the colloidal and soluble phases of milk at low-temperature. Journal of Dairy Research 48(3), 417-428.

Ramachandra Rao, H.G., Lewi, M.J., Grandison, A.S., (1995). Effect of pH on flux during ultrafiltration of sweet whey and buttermilk. Journal of Dairy Research 62, 441449 .

Saffon, M., (2013). Development of a new dairy ingredient for the utilization of buttermilk constituents, Department of Food Science and Technology. Laval University, Quebec City. 
Sawyer, W.H., (1968). Heat denaturation of bovine beta lactoglobulins and relevance of disulfide aggregation. Journal of Dairy Science 51(3), 323-329.

Sawyer, W.H., Coulter, S.T., Jenness, R., (1963). Role of sulfhydryl groups in the interaction ok kappa- casein and beta- lactoglobulin. Journal of Dairy Science 46(6), 564565.

Schmidt, D., (1980). Colloidal aspects of casein. Netherlands milk ans dairy journal 34(1), 42-64.

Schokker, E.P., Singh, H., Pinder, D.N., Norris, G.E., Creamer, L.K., (1999). Characterization of intermediates formed during heat-induced aggregation of betalactoglobulin AB at neutral pH. International Dairy Journal 9, 791-800.

Singh, H., (2006). The milk fat globule membrane - A biophysical system for food applications. Current Opinion in Colloid \& Interface Science 11, 154-163.

Smits, P., van Brouwershaven, J.H., (1980). Heat-induced association of betalactoglobulin and casein micelles. Journal of Dairy Research 47, 313-325.

Sodini, I., Morin, P., Olabi, A., Jiménez-Flores, R., (2006). Compositional and Functional Properties of Buttermilk : A comparison between sweet, sour, and whey buttermilk. Journal of Dairy Science 89, 525-536. 
Spitsberg, V.L., (2005). Invited Review: Bovine milk fat globule membrane as a potential nutraceutical. Journal of Dairy Science 88(7), 2289-2294.

Stammers, M., Rowen, L., Rhodes, D., Trowsdale, J., Beck, S., (2000). BTL-II: a polymorphic locus with homology to the butyrophilin gene family, located at the border of the major histocompatibility complex class II and class III regions in human and mouse. Immunogenetics 51(373-382).

Swaisgood, H.E., (2003). Chemistry of the caseins, Advanced Dairy Chemistry 1: Proteins. Kluver Academic/Plenum Press, New York, N.Y., USA.

Thompson, A., Boland, M., Singh, H., (2009). Milk proteins: from expression to food. Elsevier, Amsterdam.

Turcot, S., St.Gelais, D., Turgeon, S.L., (2002). Affinage de fromages allégés de type Cheddar fabriqués à partir de laits enrichis en phospholipides. Lait 82, 209-223.

Turcot, S., Turgeon, S.L., St.Gelais, D., (2001). Effet de la concentration en phospholipides de babeurre dans le lait de fromagerie sur la production et la composition de fromages allégés de type Cheddar. Le lait 81, 429-442.

USDA, (2013). Dairy Products - 2012 Summary, National Agriculture Statistics Service. 
Vanderghem, C., Bodson, P., Danthine, S., Paquot, M., Deroanne, C., Blecker, C., (2010). Milk fat globule membrane and buttermilks: from composition to valorization. Biotechnology, Agronomy, Society and Environment 14(3), 485-500.

Vasbinder, A.J., Alting, A.C., De Kruif, K.G., (2003). Quantification of heat-induced casein-whey protein interactions in milk and its relation to gelation kinetics. Colloids and Surfaces B: Biointeraces(31), 115-123.

Walstra, P., Geurts, T.J., Noomen, A., Jellema, A., van Boekel, M.A.J.S., (1999). Dairy technology - Principles of milk properties and processes. Marcel Dekker AG, New York, NY.

Walstra, P., Wouters, J.T.M., Geurts, T.J., (2006). Dairy Science and Technology Handbook Second Edition.

Wang, W., Nema, S., Teagarden, D., (2010). Protein aggregation - Pathways and influencing factors. International Journal of Pharmaceutics 390, 89-99.

Ye, A., Anema, S.G., Singh, H., (2004a). High-pressure-induced interactions between milk fat globule membrane proteins and skim milk proteins in whole milk. Journal of Dairy Science 87, 4013-4022. 
Ye, A., Singh, H., Oldfield, D.J., Anema, S., (2004b). Kinetics of heat-induced association of $\beta$-lactoglobulin and $\alpha$-lactalbumin with milk fat globule membrane in whole milk. International Dairy Journal 14, 389-398.

Ye, A., Singh, H., Taylor, M.J., Anema, S., (2002). Characterization of protein components of natural and heat-treated milk fat globule membranes. International Dairy Journal 12, 393-402.

Ye, A., Singh, H., Taylor, M.W., Anema, S., (2004c). Interactions of whey proteins with milk fat globule membrane proteins during heat treatment of whole milk. Lait 84, 269283.

Zheng, H., Jiménez-Flores, R., Everett, D.W. (2013). Centrifugal washing processes reveal lipid organization of bovine milk fat globule membrane (MFGM) ADSA, Indianapolis, IN. 